Portland State University

PDXScholar

1973

\title{
Synthesis of Uranium Fluorosulfates and the Group VI B Difluorophosphates
}

Larry McCain Emme

Portland State University

Follow this and additional works at: https://pdxscholar.library.pdx.edu/open_access_etds

Part of the Chemistry Commons

Let us know how access to this document benefits you.

\section{Recommended Citation}

Emme, Larry McCain, "Synthesis of Uranium Fluorosulfates and the Group VI B Difluorophosphates" (1973). Dissertations and Theses. Paper 1593.

https://doi.org/10.15760/etd.1593

This Thesis is brought to you for free and open access. It has been accepted for inclusion in Dissertations and Theses by an authorized administrator of PDXScholar. Please contact us if we can make this document more accessible: pdxscholar@pdx.edu. 
AN ABSTRACT OF THE THESIS OF Larry McCain Emme for the Master of Science in Chemistry August 10, 1973.

Title: Synthesis of Uranium Fluorosulfates and Group VI B Difluorophosphates

APPROVED BY MEMBERS OF THE THESIS COMMITTEE:

Gary L: Gard, Chairman

M. B. Silverman

D. W. Barnum

Some reactions leading to several anhydrous Uranium fluorosulfates through the use of fluorosulfonic acid or peroxydisulfuryl di• fluoride have been studied. It was found that $\mathrm{HSO}_{3} \mathrm{~F}$ can oxidize uranium metal to the +4 state or the +2 state depending on the reaction conditions. The synthesis of the tan solid; $U\left(\mathrm{SO}_{3} \mathrm{~F}\right)_{4}$, and the pale green solid thought to be $\mathrm{U}\left(\mathrm{SO}_{3} \mathrm{~F}\right)_{2}$ were prepared in this manner.

It was found that $\mathrm{S}_{2} \mathrm{O}_{6} \mathrm{~F}_{2}$ can also oxidize uranium to yield the green solid $\mathrm{U}\left(\mathrm{SO}_{3} \mathrm{~F}\right)_{3} \cdot \mathrm{S}_{2} \mathrm{O}_{6} \mathrm{~F}_{2}$ was also found to be a convenient reagent for placing a fluorosulfonate group on uranium tetrahalides to form addition or displacement products; the yellow solid $\mathrm{UF}_{4}\left(\mathrm{SO}_{3} \mathrm{~F}\right)_{2}$ and the 
tan solid $U\left(\mathrm{SO}_{3} \mathrm{~F}\right)_{4}$, were prepared in this manner.

Other reactions involving the fluorosulfate, $\left.\mathrm{U}_{\left(\mathrm{SO}_{3}\right.} \mathrm{F}\right)_{4}$, as a reactant are also discussed.

Analytical data and infrared spectra are reported for the compounds and $x$-ray powder data and magnetic susceptibility data are presented for $\mathrm{U}\left(\mathrm{SO}_{3} \mathrm{~F}\right)_{2}$ and $\mathrm{U}\left(\mathrm{SO}_{3} \mathrm{~F}\right)_{4}$.

The reaction of the fluorinated anhydride $\mu$-oxo-bis (phosphoryl difluoride), $\mathrm{P}_{2} \mathrm{O}_{3} \mathrm{~F}_{4}$, with some group VI B metal oxide salts has found to form the corresponding difluorophosphates. Five new compounds were prepared; $\mathrm{KCrO}_{2}\left(\mathrm{PO}_{2} \mathrm{~F}_{2}\right)_{3} \cdot \mathrm{P}_{2} \mathrm{O}_{3} \mathrm{~F}_{4}, \mathrm{Cs}_{2} \mathrm{CrO}_{2}\left(\mathrm{PO}_{2} \mathrm{~F}_{2}\right)_{4}, \mathrm{Na}_{2} \mathrm{MoO}_{2}$ $\left(\mathrm{PO}_{2} \mathrm{~F}_{2}\right)_{4}, \mathrm{Na}_{2} \mathrm{WO}_{2}\left(\mathrm{PO}_{2} \mathrm{~F}_{2}\right)_{4}$. Physical constants, analytical data and infrared spectra are presented supporting the proposed structures for these compounds.

A method for the preparation of $\mathrm{K}_{2} \mathrm{CrO}_{2}\left(\mathrm{CF}_{3} \mathrm{SO}_{3}\right)_{4}$ from $\mathrm{K}_{2} \mathrm{CrO}_{4}$ and $\left(\mathrm{CF}_{3} \mathrm{SO}_{2}\right)_{2} \mathrm{O}$ is also presented. Analytical data, infrared spectra and the $x$-ray powder spectra for this compound are given. 


\title{
SYNTHESIS OF URANIUM FLUOROSULFATES AND \\ GROUP VI B DIFLUOROPHOSPHATES
}

by

\section{LARRY MCCAIN EMME}

A thesis submitted in partial fulfillment of the requirements for the degree of

\author{
MASTER OF SCIENCE \\ in \\ CHEMISTRY
}

Portland State University

1973 
TO THE OFFICE OF GRADUATE STUDIES AND RESEARCH:

The members of the Committee approve the thesis of

Larry McCain Emme presented August 10, 1973.

G.L. Gard, Chairman

M. B. Silverman

D. W. Barnum

APPROVED :

Gary L. Gard, Chairman, Department of Chemistry

David T. Clark, Dean of Graduate Studies and Research

November 2, 1973 


\section{ACKNOWLEDGEMENT}

The author wishes to express his appreciation to Professor Gary L. Gard for his interest in this work; to Mr. Steven D. Brown for the preparation of the Peroxydisulfuryl Difluoride and for the instruction in vacuum line technique; and especially to Mr. Patrick J. Green who made and repaired most of the glassware. 
TABLE OF CONTENTS

Page

ACKNOWLEDGEMENT . . . . . . . . . . . . . . . 11 . .

LIST OF TABLES . . . . . . . . . . . . . . vi vi

IIST OF FIGURES . . . . . . . . . . . . . . . vii

\section{CHAPTER}

I INTRODUCTION. . . . . . . . . . . . . 1

Fluorosulfates ............... . . 1

Difluorophosphates ........... 6

II EXPERIMENTAL. . . . . . . . . . . 10

Apparatus. . . . . . . . . . . . 10

Physical Methods .............. 10

Reagents . . . . . . . . . . . . 11

III SYNTHESIS OF URANIUM FLUOROSULFATES . . . . . . . 16

The Reaction of Fluorosulfonic Acid

with Uranium Metal. ............. 16

The Reaction of Peroxydisulfuryl

Difluoride with Anhydrous Uranium

Tetrachloride... . . . . . . . . . 22

Other Reactions Involving Peroxy-

disulfuryl Difluoride. . . . . . . . . 28

Behavior of $\mathrm{S}_{2} \mathrm{O}_{6} \mathrm{~F}_{2}$ on $\mathrm{UF}_{4}$........ 28

Behavior of $\mathrm{S}_{2} \mathrm{O}_{6} \mathrm{~F}_{2}$ on U Metal. . . . . 30

Reactions Involving Uranium (IV)
Fluorosulfate as a Reactant .......... 31

Reaction of $\mathrm{CH}_{3} \mathrm{CN}$ with $\mathrm{U}\left(\mathrm{SO}_{3} \mathrm{~F}\right)_{4}$..... 31 
Reaction of $\mathrm{NaSO}_{3} \mathrm{~F}$ with $\mathrm{U}\left(\mathrm{SO}_{3} \mathrm{~F}\right)_{4}$ - . . 32

IV REACTIONS OF GROUP VI METAL OXIDE SALTS

WITH FLUORINATED ANHYDRIDES. . . . . . . . .

Reaction of $\boldsymbol{\mu}$-Oxo-bis (Phopshoryl-

difluoride) with Group VI B Metal

Oxide Salts............. 37

Introduction . . . . . . . . 37

Experimenta1 .......... 38

Preparations.......... . 38

$\mathrm{KCrO}_{2}\left(\mathrm{PO}_{2} \mathrm{~F}_{2}\right)_{3} \cdot \mathrm{P}_{2} \mathrm{O}_{3} \mathrm{~F}_{4}$...... 39

$\mathrm{Cs}_{2} \mathrm{CrO}_{2}\left(\mathrm{PO}_{2} \mathrm{~F}_{2}\right)_{4} \cdot \cdots \cdot . . . . . .39$

$\mathrm{Na}_{2} \mathrm{MoO}_{2}\left(\mathrm{PO}_{2} \mathrm{~F}_{2}\right)_{4} \cdot \cdots \cdot \cdot \cdot \cdot \cdot 39$

$\mathrm{Na}_{2} \mathrm{WO}_{2}\left(\mathrm{PO}_{2} \mathrm{~F}_{2}\right)_{4} \cdots \cdot \cdots \cdot \cdots$

Chemical Analysis ........ 40

Infrared Spectra .......... 40

Reaction of $\left(\mathrm{CF}_{3} \mathrm{SO}_{2}\right)_{2} \mathrm{O}$ with $\mathrm{K}_{2} \mathrm{CrO}_{4} \cdot \cdots \cdot . \cdot 47$

Introduction ... . . . . . . . 47

Experimenta1 ............ . 47

Preparation .......... . 47

Chemical Analysis......... 47

Infrared spectra. . . . . . . 47

X-Ray Powder Photograph ...... 47

BIBLIOGRAPHY . . . . . . . . . . . . . 51 


\section{LIST OF TABLES}

\section{TABLES}

PAGE

I X-Ray Powder Spectra for $\mathrm{U}\left(\mathrm{OSO}_{2} \mathrm{~F}\right)_{2}$ - . . . . . 20

II X-Ray Powder Spectra for $U\left(\mathrm{OSO}_{2} \mathrm{~F}\right)_{4} \ldots \ldots \ldots$

III X-Ray Powder Spectra for $\mathrm{Na}_{2}\left[\mathrm{U}\left(\mathrm{SO}_{3} \mathrm{~F}\right)_{6}\right] \ldots \ldots$

IV Analytical Data for Difluorophosphates . . . . . . 41

V Infrared Absorption Bands for Difluorophosphates . . . 42

VI X-Ray Powder Spectra for $\mathrm{K}_{2} \mathrm{CrO}_{2}\left(\mathrm{CF}_{3} \mathrm{SO}_{3}\right)_{4} \ldots \ldots . . . . \quad 50$ 
LIST OF FIGURES

FIGURES

PAGE

1 Fluorosulfonic Acid Storage Vessel . . . . . . . 13

2 Infrared Spectrum of $\mathrm{U}\left(\mathrm{SO}_{3} \mathrm{~F}\right)_{2} \cdot \ldots . . . . . . . .21$

3 Infrared Spectrum of $\mathrm{U}_{\left(\mathrm{SO}_{3} \mathrm{~F}\right)_{4}}$. . . . . . . . 27

4. Infrared Spectrum of $\mathrm{UF}_{4}\left(\mathrm{SO}_{3} \mathrm{~F}\right)_{2} \cdot \ldots . . . . . . .29$

5 Infrared Spectrum of $\mathrm{U}\left(\mathrm{SO}_{3} \mathrm{~F}\right)_{4} \cdot 3 \mathrm{CH}_{3} \mathrm{CN}$. . . . . 33

6 Infrared Spectrum of $\mathrm{Na}_{2}\left[\mathrm{U}\left(\mathrm{SO}_{3} \mathrm{~F}\right)_{6}\right] \ldots \ldots 36$

7 Infrared spectrum of $\mathrm{KCrO}_{2}\left(\mathrm{PO}_{2} \mathrm{~F}_{2}\right)_{3} \cdot \mathrm{P}_{2} \mathrm{O}_{3} \mathrm{~F}_{4} \cdot \cdots . . .43$

8 Infrared spectrum of $\mathrm{Cs}_{2} \mathrm{CrO}_{2}\left(\mathrm{PO}_{2} \mathrm{~F}_{2}\right)_{4} \ldots . . . . . . .44$

9 Infrared spectrum of $\mathrm{Na}_{2} \mathrm{MoO}_{2}\left(\mathrm{PO}_{2} \mathrm{~F}_{2}\right)_{4} \ldots . . . . . .45$

10 Infrared Spectrum of $\mathrm{Na}_{2} \mathrm{WO}_{2}\left(\mathrm{PO}_{2} \mathrm{~F}_{2}\right)_{4} \cdot \ldots . . . . . .46$

11 Infrared Spectrum of $\mathrm{K}_{2} \mathrm{CrO}_{2}\left(\mathrm{CF}_{3} \mathrm{SO}_{3}\right)_{4} \ldots . . . . . .48$ 


\section{CHAPTER I}

\section{INTRODUCTION}

\section{Flurosulfates}

Fluorosulfonic acid was first prepared in 1892 by Thorpe and Rirman (1) who obtained it by combining sulfur trioxide and anhydrous hydrogen fluoride,

$$
\mathrm{SO}_{3}+\mathrm{HF}=\mathrm{HSO}_{3} \mathrm{~F}
$$

However, it was not until 20 years later that the first fluorosulfonate salts were prepared, when Traube studied the reaction of gaseous sulfur trioxide with ammonium or sodium fluoride. Traube described several ways to prepare fluorosulfates $(2,3)$ :

a. The intereaction of gaseous sulfur trioxide with fluoride salts,

$$
\mathrm{NH}_{4} \mathrm{~F}+\mathrm{SO}_{3}=\mathrm{NH}_{4} \mathrm{SO}_{3} \mathrm{~F}
$$

b. The reaction of fluorides with fuming sulfuric acid

c. The dry heating of fluorides with pyrosulfates,

$$
\mathrm{Na}_{2} \mathrm{~S}_{2} \mathrm{O}_{7}+\mathrm{NaF}=\mathrm{Na}_{2} \mathrm{SO}_{4}+\mathrm{NaSO}_{3} \mathrm{~F}
$$

d. The neutralization of an aqueous solution of fluorosulfonic acid.

From aqueous solutions, Traube was only able to isolate the alkal1 fluorosulfates; attempts to isolate the salts of other metals resulted in decomposition by hydrolysis. 
The first method of Traube is the most common way of preparing fluorosulfates and has been a versatile route, as seen in the following reactions :

$$
\begin{aligned}
\mathrm{BaF}_{2}+2 \mathrm{SO}_{3} & =\mathrm{Ba}\left(\mathrm{SO}_{3} \mathrm{~F}\right)_{2} \\
\mathrm{TlF}+\mathrm{SO}_{3} & =\mathrm{T} 1 \mathrm{SO}_{3} \mathrm{~F} \\
\mathrm{ClO}_{2} \mathrm{~F}+\mathrm{SO}_{3} & =\mathrm{ClO}_{2} \mathrm{SO}_{3} \mathrm{~F}
\end{aligned}
$$

Fluorosulfonic acid has also been found to be an excellent fluorosulfonating agent. Meyer and Schramm prepared esters by reacting fluorosulfonic acid with alcohols or their corresponding ethers (10);

$$
\begin{aligned}
& \mathrm{C}_{2} \mathrm{H}_{5} \mathrm{OH}+\mathrm{HSO}_{3} \mathrm{~F}=\mathrm{C}_{2} \mathrm{H}_{5} \cdot \mathrm{O} \cdot \mathrm{SO}_{2} \mathrm{~F} \\
& \left(\mathrm{CH}_{3}\right)_{2} \mathrm{O}+\mathrm{HSO}_{3} \mathrm{~F}=\mathrm{CH}_{3} \cdot \mathrm{O} \cdot \mathrm{SO}_{2} \mathrm{~F}
\end{aligned}
$$

Fluorosulfonic acid was also found by Traube (11) and later Calfee (12) to add directly to alkenes:

$$
\begin{aligned}
& \mathrm{HSO}_{3} \mathrm{~F}+\mathrm{C}_{2} \mathrm{H}_{4}=\mathrm{C}_{2} \mathrm{H}_{5} \cdot 0 \cdot \mathrm{SO}_{2} \mathrm{~F} \\
& \mathrm{HSO}_{3} \mathrm{~F}+\mathrm{CH}_{2} \mathrm{CF}_{2}=\mathrm{CH}_{3} \mathrm{CF}_{2} \cdot \mathrm{O} \cdot \mathrm{SO}_{2} \mathrm{~F}
\end{aligned}
$$

Other fluorosulfonates that have been prepared: nitrosyl fluorosulfonate, $\mathrm{NOSO}_{3} \mathrm{~F}$, from dinitrogen trioxide and fluorosulfonic acid (13); Nitronium fluorosulfate from dinitrogen pentoxide and fluorosulfonic acid (14); $\mathrm{AlCl}\left(\mathrm{SO}_{3} \mathrm{~F}\right)_{2}, \mathrm{SnCl}_{2}\left(\mathrm{SO}_{3} \mathrm{~F}\right)_{2}$, and $\operatorname{TiCl}_{2}\left(\mathrm{SO}_{3} \mathrm{~F}\right)_{2}$ from the metal chloride and fluorosulfonic acid (15). Fluorosulfates have also been made (16) by the reaction of iodoalkanes and fluorosulfonic acid, 


$$
\mathrm{CF}_{3} \mathrm{CF}_{2} \mathrm{CF}_{2} \mathrm{I}+\mathrm{HSO}_{3} \mathrm{~F}=\mathrm{CF}_{3} \mathrm{CF}_{2} \mathrm{CF}_{2} \cdot \mathrm{O} \cdot \mathrm{SO}_{2} \mathrm{~F}+\mathrm{HI}
$$

In addition to the general method of preparing the alkali, alkaline earth, and ammonium fluorosulfates through the use of sulfur trioxide, an alternative procedure has been used based on the reaction of fluorosulfonic acid with fluorides $(17,18)$ or chlorides $(19,20,21)$ accompanied by the liberation of $\mathrm{HF}$ or $\mathrm{HCl}$. The general scheme for these reactions is as follows (17):

$$
\begin{aligned}
\mathrm{MCl}_{x}+\mathrm{yHSO}_{3} \mathrm{~F}= & \mathrm{MC1}_{\mathrm{x}-\mathrm{y}}\left(\mathrm{SO}_{3} \mathrm{~F}\right)_{\mathrm{y}}+\mathrm{y} \mathrm{HCl} \\
& \mathrm{M}=\mathrm{Ti}^{+4}, \mathrm{Sn}^{+4}, \mathrm{Ta}^{+5}, \mathrm{Sb}^{+5}
\end{aligned}
$$

Sometimes, however, chloride -, fluoride - and oxide fluorosulfates are formed during these reactions $(15,17,21,22)$ :

$$
\begin{gathered}
M\left(\mathrm{SO}_{3} \mathrm{~F}\right)_{\mathrm{X}}=\mathrm{MO}_{3}\left(\mathrm{SO}_{3} \mathrm{~F}\right)_{\mathrm{X}-2}+\mathrm{S}_{2} \mathrm{O}_{5} \mathrm{~F}_{2} \\
\mathrm{M}=\mathrm{Al}^{+3}, \mathrm{Sb}^{+3}, \mathrm{Nb}^{+5}, \mathrm{~W}^{+6} \\
. \mathrm{MCl}_{4}+4 \mathrm{HSO}_{3} \mathrm{~F}=\mathrm{MF}_{2,3}\left(\mathrm{SO}_{3} \mathrm{~F}\right)_{2,1}+(2,1) \mathrm{HCl}+2,3 \mathrm{HSO}_{3} \mathrm{Cl} \\
\mathrm{M}=\mathrm{Th}^{+4}, \mathrm{Zr}^{+4}
\end{gathered}
$$

The first anhydrous fluorosulfates of transition metals were prepared in 1967 by Woolf (23). He prepared the anhydrous fluorosulfates of $\mathrm{Mn}, \mathrm{Fe}, \mathrm{Co}, \mathrm{Ni}, \mathrm{Cu}, \mathrm{Zn}$ and $\mathrm{Cd}$ by displacement reactions in fluorosilfonic acid. He found that the ease of displacement in these heterogeneous reactions is in the decreasing order $\mathrm{CH}_{3} \mathrm{CO}_{2}{ }^{-}$, $\mathrm{SO}_{4}^{-2}, \mathrm{Cl}^{-}, \mathrm{F}^{-}$. Earlier observations of his (24) indicated that uranium metal dissolves in fluorosulfonic acid to yield a green solution, however, the reaction products were not characterized. The 
green color of the solution suggested that uranium is in the +4 oxidation state. Study of the product in the present paper has yielded the identification of the compound, $\mathrm{U}\left(\mathrm{SO}_{3} \mathrm{~F}\right)_{4}$, uranium tetrakisfluorosulfate.

Other fluorosulfates have recently been made by the reactions of xenon fluorides with fluorosulfonic acid (25):

$$
\begin{aligned}
& \mathrm{XeF}_{6}+\mathrm{HSO}_{3} \mathrm{~F}=\mathrm{F}_{5} \mathrm{XeOSO}_{2} \mathrm{~F}+\mathrm{HF} \\
& \mathrm{XeF}_{4}+4 \mathrm{HSO}_{3} \mathrm{~F}=\mathrm{Xe}\left(\mathrm{OSO}_{2} \mathrm{~F}_{2}+\mathrm{S}_{2} \mathrm{O}_{6} \mathrm{~F}_{2}+4 \mathrm{HF}\right.
\end{aligned}
$$

The reaction of peroxydisulfuryl difluoride, $\mathrm{S}_{2} \mathrm{O}_{6} \mathrm{~F}_{2}$, with sulfur dioxide to give trisulfuryl fluoride, $\mathrm{s}_{3} \mathrm{O}_{8} \mathrm{~F}_{2}$, led Roberts and Cady (26) to suggest the possibility that the reaction involved free radical formation due to the homolytic splitting of the oxygenoxygen bond yielding $f$ luorosulfonate free radicals, $\cdot \mathrm{OSO}_{2} \mathrm{~F}$, which then formed a bond with the central atom by unpairing the unshared electron pair. Aubke (27) has since demonstrated via the vibrational spectra of peroxydisulfuryl difluoride that indeed $\mathrm{s}_{2} \mathrm{O}_{6} \mathrm{~F}_{2}$ can be regarded as a true peroxide of the type $R_{2} O_{2}$ where $R=S_{3} \mathrm{~F}$.

Various anhydrous metal fluorosulfates other than uranium have been prepared through the action of peroxydisulfuryl difluoride with metals, metal carbonyls, metal chlorides, metal oxychlorides, metal oxides or carbonates (23-34). Cady and Roberts (28) found that mercury would react with $\mathrm{S}_{2} \mathrm{O}_{6} \mathrm{~F}_{2}$ to yield bis(fluorosulfonato)-mercury (II), $\mathrm{Hg}\left(\mathrm{SO}_{3} \mathrm{~F}\right)_{2}$

Shreeve and Cady in 1961, prepared the white solid dioxobis(fluorosulfonato)molybdenum (VI) through the action of $\mathrm{s}_{2} \mathrm{O}_{6} \mathrm{~F}_{2}$ on molybedenum hexacarbony1 or molybdenum metal (29): 


$$
\mathrm{Mo}(\mathrm{CO})_{6}+9 \mathrm{~S}_{2} \mathrm{O}_{6} \mathrm{~F}_{2}=\mathrm{MoO}_{2}\left(\mathrm{SO}_{3} \mathrm{~F}\right)_{2}+6 \mathrm{CO}_{2}+8 \mathrm{~S}_{2} \mathrm{O}_{5} \mathrm{~F}_{2}
$$

Lustig and Cady (1962) prepared dioxobis(fluorosulfonato) chromium (VI), $\mathrm{CrO}_{2}\left(\mathrm{SO}_{3} \mathrm{~F}\right)_{2}$, which was later prepared by Rochat and Gard (1969), by the reaction of $\mathrm{S}_{2} \mathrm{O}_{6} \mathrm{~F}_{2}$ with chromyl chloride $(30,34):$

$$
\mathrm{CrO}_{2} \mathrm{Cl}_{2}+\mathrm{S}_{2} \mathrm{O}_{6} \mathrm{~F}_{2}=\mathrm{CrO}_{2}\left(\mathrm{SO}_{3} \mathrm{~F}\right)_{2}+\mathrm{Cl}_{2}
$$

Kleinkopf and Shreeve (1964) made a systematic preparation and characterization of several transition metal compounds by the use of $\mathrm{S}_{2} \mathrm{O}_{6} \mathrm{~F}_{2}$ and a transition metal or its anhydrous chloride (31). Some of the products they obtained using $\mathrm{S}_{2} \mathrm{O}_{6} \mathrm{~F}_{2}$ as one reactant are: The viscous deep red liquid $\mathrm{VO}\left(\mathrm{SO}_{3} \mathrm{~F}\right)_{3}$ from $\mathrm{VCl}_{5}$; the viscous yellow

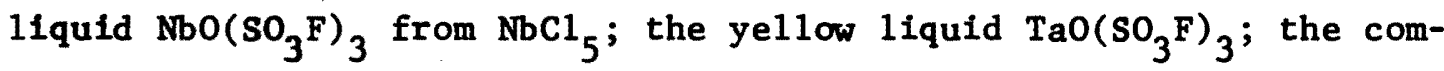
pounds dioxotris(fluorosulfato)rhenium (VII) and trioxo(fluorosulfato) rhenium (VII).

$$
\begin{aligned}
& \mathrm{Re}+\mathrm{S}_{2} \mathrm{O}_{6} \mathrm{~F}_{2}=\operatorname{ReO}_{3}\left(\mathrm{SO}_{3} \mathrm{~F}\right)+\mathrm{ReO}_{2}\left(\mathrm{SO}_{3} \mathrm{~F}\right)_{3}+\mathrm{S}_{2} \mathrm{O}_{5} \mathrm{~F}_{2} \\
& \text { yellow liquid white solid } \\
& \mathrm{Re}+\mathrm{S}_{2} \mathrm{O}_{6} \mathrm{~F}_{2} \text { (excess) }=\mathrm{ReO}_{3}\left(\mathrm{SO}_{3} \mathrm{~F}\right)+\mathrm{S}_{2} \mathrm{O}_{5} \mathrm{~F}_{2} \\
& \left.\operatorname{ReO}_{2}\left(\mathrm{SO}_{3} \mathrm{~F}\right)_{3}=\operatorname{ReO}_{3}\left(\mathrm{SO}_{3} \mathrm{~F}\right)+\mathrm{S}_{2}\right)_{5} \mathrm{~F}_{2}
\end{aligned}
$$

Dev and Cady (1971) used $\mathrm{S}_{2} \mathrm{O}_{6} \mathrm{~F}_{2}$ as a fluorosulfonating agent to make the corresponding oxyfluorosulfates from some metal carbonates (32). Some of their results using $\mathrm{S}_{2} \mathrm{O}_{6} \mathrm{~F}_{2}$ as one reactant are: $\mathrm{MnOSO}_{3} \mathrm{~F}$ (brownish black); $\mathrm{CoOSO}_{3} \mathrm{~F}$ (chocolate); $\mathrm{NiOSO}_{3} \mathrm{~F}$ (grayish black); $\mathrm{Ag}_{2} \mathrm{O}\left(\mathrm{SO}_{3} \mathrm{~F}\right)_{2}$ (black); $\mathrm{T} \mathrm{OSO}_{3} \mathrm{~F}$ (brown).

Recently Dev and Cady (33) have also prepared oxotetrakis(fluoro- 
sulfato) tungsten (VI) through the action of peroxydisulfuryl difluo- : ride on tungsten hexacarbonyl, tungsten oxytetrachloride, and tungsten hexachloride.

\section{Difluorophosphates}

Difluorophosphorlc acld, HOPOF 2 , was first observed by Tarbutton (35) during a study of the interaction of $\mathrm{P}_{4} \mathrm{O}_{10}$ and $\mathrm{CaF}_{2}$ where traces of water may have reacted with the $\mathrm{POF}_{3}$ formed. Lange (36) later prepared the acid through the reaction of $\mathrm{POF}_{3}$ with monofluorophosphoric acid in a $1: 1$ molar ratio:

$$
\mathrm{H}_{2} \mathrm{PO}_{3} \mathrm{~F}+\mathrm{POF}_{3} \longrightarrow 2 \mathrm{HOPOF}_{2}
$$

The acid is made commercially by reaction of HF with $\mathrm{P}_{4} \mathrm{O}_{10}$ (37). The acid made in this way is difficult to prepare and is usually quite impure as monofluorophosphoric acid is also a by product of the reaction. These preparations of the acid have probably lead to the small amount of work done in the area of preparation of difluorophosphates that has appeared in the literature until recently.

Preparations of difluorophosphates were first begun by Lange (36). He found that upon dissolving $\mathrm{POF}_{3}$ in cold water and then addition of nitron acetate, the nitron salt of difluorophosphoric acid was obtained:

$$
\mathrm{POF}_{3} \underset{-\mathrm{HF}}{\stackrel{\mathrm{H}_{2} \mathrm{O}}{\rightarrow}} \mathrm{HOPOF}_{2} \underset{\text { nitron- }}{\text { acetate }} \text { nitron } \cdot \mathrm{POF}_{2} \text { • }
$$

The reaction of alkali hexafluorophosphates with metaphosphates or certain oxides such as $\mathrm{B}_{2} \mathrm{O}_{3}$ have given good yields of pure difluorophosphates (38): 


$$
\begin{aligned}
& \mathrm{NaPF}_{6}+2 \mathrm{NaPO}_{3}=3 \mathrm{NaPO}_{2} \mathrm{~F}_{2} \\
& 3 \mathrm{KPF}_{6}+2 \mathrm{~B}_{2} \mathrm{O}_{3}=3 \mathrm{KPO}_{2} \mathrm{~F}_{2}+4 \mathrm{BF}_{3}
\end{aligned}
$$

Stolzer and simon (39) have formed difluorophosphates through the dealkylation of phosphorodifluoridates, ROPOF 2 , by tertiary amines, thiourea, and various acid anions:

$$
\begin{aligned}
& \mathrm{C}_{2} \mathrm{H}_{5} \mathrm{OPOF}_{2}+\left(\mathrm{C}_{2} \mathrm{H}_{5}\right)_{3} \mathrm{~N}=\mathrm{PO}_{2} \mathrm{~F}_{2}{ }^{-} \mathrm{N}\left(\mathrm{C}_{2} \mathrm{H}_{5}\right)_{4}+ \\
& \mathrm{C}_{2} \mathrm{H}_{5} \mathrm{OPOF}_{2}+\left(\mathrm{NH}_{2}\right)_{2} \mathrm{CS}=\mathrm{PO}_{2} \mathrm{~F}_{2}^{-} \stackrel{+}{\left[\left(\mathrm{NH}_{2}\right)_{2} \mathrm{CsC}_{2} \mathrm{H}_{5}\right]} \\
& \mathrm{C}_{2} \mathrm{H}_{5} \mathrm{OPOF}_{2}+\mathrm{NaI}=\mathrm{Na}^{+} \mathrm{PO}_{2} \mathrm{~F}_{2}^{-}+\mathrm{C}_{2} \mathrm{H}_{5} \mathrm{I}
\end{aligned}
$$

Weidlein (1968) has demonstrated the preparation of the first transition metal difluorophosphates through the direct fluorination of the corresponding dichlorophosphates (40):

$$
\begin{aligned}
\mathrm{M}\left(\mathrm{O}_{2} \mathrm{PCl}_{2}\right)_{3}+3 \mathrm{~F}_{2} & =\mathrm{M}\left(\mathrm{O}_{2} \mathrm{PF}_{2}\right)_{3}+3 \mathrm{Cl}_{2} \\
\mathrm{M} & =\mathrm{In} \text { and } \mathrm{Fe} \\
\mathrm{MO}\left(\mathrm{O}_{2} \mathrm{PCl}_{2}\right)_{2}+2 \mathrm{~F}_{2} & =\mathrm{MO}\left(\mathrm{O}_{2} \mathrm{PF}_{2}\right)_{2}+2 \mathrm{Cl}_{2} \\
\mathrm{M} & =\mathrm{TI}
\end{aligned}
$$

Titanyldichlorophosphate was prepared from $\mathrm{TiCl}_{4}, \mathrm{POCl}_{3}$ and $\mathrm{Cl}_{2} \mathrm{O}$.

More recently (1969) Thompson and Reed (41) reported the preparation of ammonium and alkali metal difluorophosphates by the reaction of the appropriate chloride with difluorophosphoric acid, a procedure that is analogous to the preparation of some fluorosufonates (42).

Very little chemistry of $\mu$ - oxo-bis(phosphoryl difluoride), $\mathrm{P}_{2} \mathrm{O}_{3} \mathrm{~F}_{4}$, has appeared in the open literature since its initial isolation by Wannogat (43) who prepared it through the reaction of $\mathrm{PF}_{3}$ with $\mathrm{O}_{2}$ 
In electrical discharge. Robinson (44) later prepared the anhydride by dehydration of HOPOF 2 with $\mathrm{P}_{4} \mathrm{O}_{10}$. Robinson's method proved to be easy to carry out. However, contamination of the product with HOPOF 2 is extensive and separation from the acid is extremely difficult.

It has not been until recently (1971) that high yields of pure $\mathrm{P}_{2} \mathrm{O}_{3} \mathrm{~F}_{4}$ have been obtained through the photolysis of $\mathrm{POF}{ }_{2} \mathrm{Br}$ with excess oxygen (45):

$$
2 \mathrm{POF}_{2} \mathrm{Br}+\frac{1}{2} \mathrm{O}_{2} \stackrel{2537 \AA}{\longrightarrow} \mathrm{P}_{2} \mathrm{O}_{3} \mathrm{~F}_{4}+\mathrm{Br}_{2}
$$

The similarity between $\mathrm{HOPOF}_{2}$ and $\mathrm{HOSO}_{2} \mathrm{~F}$ is noteworthy. The difluorophosphate radical, $\mathrm{OPOF}_{2}$, would be isoelectronic with $\mathrm{SO}_{3} \mathrm{~F}$ and might form many compounds resembling fluorosulfonates.

Preliminary investigations of uranyl compounds by $R$. Goldstein of this laboratory have lead to the preparation of $\mathrm{UO}_{2}\left(\mathrm{SO}_{3} \mathrm{~F}\right)_{2}$ from reaction of $\mathrm{UO}_{3}$ and $\mathrm{S}_{2} \mathrm{O}_{6} \mathrm{~F}_{2}$ and also the preparation of $\mathrm{UO}_{2}\left(\mathrm{PO}_{2} \mathrm{~F}_{2}\right)_{2}$ from reaction of $\mathrm{UO}_{3}$ and $\mathrm{P}_{2} \mathrm{O}_{3} \mathrm{~F}_{4}$.

Other work in this laboratory by $s$. Brown on the reaction of $\mathrm{P}_{2} \mathrm{O}_{3} \mathrm{~F}_{4}$ with some chromium compounds have yielded $\mathrm{Cr}\left(\mathrm{PO}_{2} \mathrm{~F}_{2}\right)_{3}$ and $\mathrm{K}_{2} \mathrm{CrO}_{2}\left(\mathrm{PO}_{2} \mathrm{~F}_{2}\right)_{4}:$

$$
\begin{aligned}
& 2 \mathrm{CrO}_{3}+3 \mathrm{P}_{2} \mathrm{O}_{3} \mathrm{~F}_{4}=2 \mathrm{Cr}\left(\mathrm{PO}_{2} \mathrm{~F}_{2}\right)_{3}+3 / 2 \mathrm{O}_{2} \\
& \mathrm{R}_{2} \mathrm{CrO}_{4}+2 \mathrm{P}_{2} \mathrm{O}_{3} \mathrm{~F}_{4}=\mathrm{K}_{2} \mathrm{CrO}_{2}\left(\mathrm{PO}_{2} \mathrm{~F}_{2}\right)_{4}
\end{aligned}
$$

Before the work presented in this paper, no difluorophosphate had been reported using the reactant $\mathrm{P}_{2} \mathrm{O}_{3} \mathrm{~F}_{4}$ except for the compound trifluoromethoxyphosphoryl difluoride (46):

$$
\mathrm{P}_{2} \mathrm{O}_{3} \mathrm{~F}_{4}+\mathrm{CF}_{3} \mathrm{COOH}=\mathrm{CF}_{3} \mathrm{OPOF}_{2}+\mathrm{HOPOF}_{2}
$$


The preparation of several new difluorophosphates through the reaction of metal oxide salts and $\mathrm{P}_{2} \mathrm{O}_{3} \mathrm{~F}_{4}$ presented in this paper is a further investigation in the class of reactions of metal oxide salts with fluorinated anhydrides that was begun by J.N. Gerlach and G. L. Gard (47). 
CHAP TER II

EXPERIMENTAL

\section{A. Apparatus}

1. Vacuum System. The vacuum system used in this research consisted of a manifold connected to a Duo seal vacuum pump. The manifold was constructed of $12 \mathrm{~mm}$ O.D. Pyrex glass tubing and was connected to a two leg mercury manometer and several taps. The taps consisted of three Kontes high vacuum teflon valve stopcocks of $0-4 \mathrm{~mm}$ bore, and ended in $10 / 30 \mathrm{~S}$ outer Pyrex glass joints. The vacuum pump was protected by a large concentric trap which was cooled with liquid nitrogen. A Televac thermocouple vacuum gauge monitored the vacuum, which was maintained from $10^{-3}$ to $10^{-2}$ torr. A11 joints were lubricated with Halocarbon batch 9970 grease.

2. Réaction Vessels. A11 reactions were run in either 0.1 liter or 0.2 liter Pyrex glass bulbs closed with a Kontes high vacuum teflon valve of $0-4 \mathrm{~mm}$ bore or a Eck and Krebs $2 \mathrm{~mm}$ high vacuum valve respectively. The valves were tipped with a 10/30 S inner Pyrex glass joint for attaching to the vacuum line.

B. Physical Methods

1. Infrared Spectra. The infrared spectra were studied by the use of a Perkin-Elmer Model 467 infrared spectrophotometer. Infrared spectra of gaseous by-products were obtained with the use of a monel metal cell ( $\mathrm{NaCl}$ windows) equipped with a whitney $\mathrm{Brass}$ valve which was 
connected to a glass $10 / 30 \mathrm{~g}$ inner Pyrex glass goint for attaching to the vacuum line. The path length of the cell is $8.25 \mathrm{~cm}$. . The spectra of the solid products were obtained either neat between CsBr windows or by the use of a $\mathrm{KBr}$ minipress.

2. Chemical Analysis. Chemical analysis of the solid products obtained in this research were performed by Beller Microanalytical Laboratory in Gottingen, West Germany.

3t X-Ray Powder Spectra. Powder spectra for all compounds were obtained using an XRD-5 General Electric camera. Samples were contained in $0.5 \mathrm{~mm}$ Lindermann glass capillaries. Since the compounds were all very sensitive to water vapor, samples were placed in the captllaries in a dry box. Nickel-filtered copper $\mathrm{K} \alpha$-radiation was used with a 6-hour exposure time. The procedure was standardized using known compounds $\left(\mathrm{K}_{2} \mathrm{CrO}_{4}, \mathrm{Na}_{2} \mathrm{MOO}_{4}, \mathrm{Na}_{2} \mathrm{WO}_{4}\right)$ in which the calculated d values agreed with published ASTM values.

4. Magnetic Susceptibility. The magnetic susceptibility values were obtained by the Gouy method. Measurements were made at a field strength of $5 \mathrm{KG}$ using an Alpha AL 7500 water-cooled magnet with 4-in. pole faces and a 1.5-in air gap. The Gouy tube was calibrated at $25^{\circ} \mathrm{C}$ and the gram-susceptibility of the callbrant, mercury (II) tetrathiocyanatocobaltate (II), was calculated (48). The procedure was standardized using $\mathrm{CuSO}_{4} \cdot 5 \mathrm{H}_{2} \mathrm{O}$. Diamagnetic corrections were made using Selwood's values (49).

\section{Reagents}

1. Peroxydisulfury 1 Difluoride. Peroxydisulfuryl difluoride 
was obtained as a gift from the laboratory of F. Aubke*, prepared by S. Brown, who made it by the method of Dudley and Cady (50). $\mathrm{S}_{2} \mathrm{O}_{6} \mathrm{~F}_{2}$ is a colorless liquid having a melting point of $-55.4^{\circ} \mathrm{C}$ and a boiling point of $67.1^{\circ} \mathrm{C}$. Its vapor pressure at $26^{\circ} \mathrm{C}$ is $146.4 \mathrm{~mm}$ which makes handling through a vacuum system relatively easy. The peroxide has an obnoxiously sweet odor. Its density is given by the equation

$$
\sigma=2.3959-2.1134 \times 10^{-3} \mathrm{~T}^{\circ} \mathrm{K}
$$

for a temperature range between $35.5^{\circ}$ and $45.0^{\circ} \mathrm{C}(50)$. It hydrolyzes violently in water to yield oxygen and fluorosulfonic acid. Peroxydisulfuryl difluoride liberates iodine from KI solution and ignites organic matter. Purification of the peroxide as received in a metal storage vessel was carried out by attaching the vessel to the vacuum system and pumping on the contents while at $-78^{\circ} \mathrm{C}$. The purity of $\mathrm{s}_{2} \mathrm{O}_{6} \mathrm{~F}_{2}$ was determined by use of infrared spectra. A pure sample was stored in a graduated glass vessel.

2. Fluorosulfonic Acid. Technical grade $\mathrm{HOSO}_{2} \mathrm{~F}$ was purchased from General Chemical Division of Allied Chemical Company. The acid was purified by double distillation at atmospheric pressure under dry nitrogen. A middle fraction was collected at $164.5^{\circ} \mathrm{C}$. In order to facilitate handling of the extremely corrosive acid while maintaining its purity, it was distilled into a $500 \mathrm{ml}$ Pyrex glass storage bulb modified fromD.D. Des Marteau (51). The vessel is shown in Figure I. Whenever some acid was needed the bulb was attached to another evacuated reaction vessel through the $10 / 30 \mathrm{~s}$ joint. Both

*Department of Chemistry, University of British Columbia, Vancouver 8, B.C. 


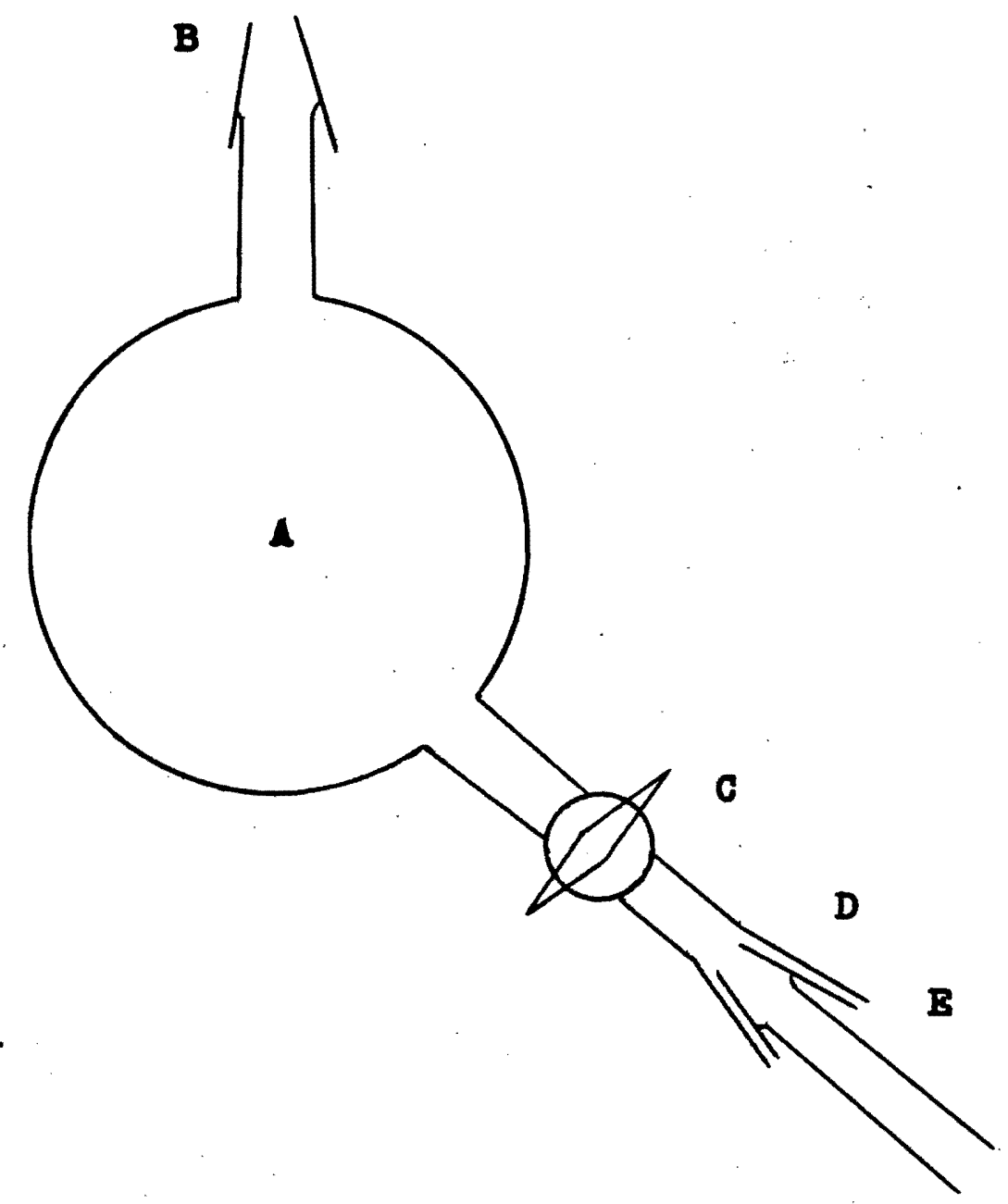

A. $500 \mathrm{ml}$ Pyrex bulb

B. $10 / 30$ innor joint for attaching to distillation epparatus

C. Kontes 0-4 min Teflon valve

D. $10 / 30$ outer joint with Teflon sleeve

E. $10 / 30$ inner joint from reaction vessel

Flgure.1. Fluorosulfonic Acid Storage Vessel. 
teflon valves were opened simultaneously allowing the acid to run into the evacuated vessel held at $-78^{\circ} \mathrm{C}$. After the desired amount of acid had been added, both valves were closed and the reaction vessel then hooked up to the vacuum system and pumped on until any trapped air was removed. .

3. $\mu$-Oxo-bis (phosphoryl difluoride). $\quad \mathrm{P}_{2} \mathrm{O}_{3} \mathrm{~F}_{4}$ was purchased from Ozark Mahoning Chemical Company. The anhydride was stated to be $96 \%$ pure and infrared analysis showed the presence of small amounts of $\mathrm{HOPOF}_{2}$. Purification was done by vacuum distillation of the liquid into a glass storage vessel. Infrared analysis of the distilled product showed it to be essentially free of $\mathrm{HOPOF}_{2}$.

4. Acetonitrile. Acetonitrile was purchased from Mallinckrodt Chemical Company. The liquid was dried by the method of Jolly (52) by refluxing with $\mathrm{P}_{4} \mathrm{O}_{10}$, followed by vacuum distillation. An infrared spectrum showed no water present.

5. Bis(Trifluoromethylsulfuryl oxide). $\left(\mathrm{CF}_{3} \mathrm{SO}_{2}\right)_{2} \mathrm{O}$ the anhydride of trifluoromethylsulfonic acid, was purchased from $3 \mathrm{M}$ Company. The liquid was vacuum distilled and its purity checked by infrared analysis.

6. Uranium Solids. Uranium metal, uranium tetrachloride and uranium tetrafluoride were purchased as anhydrous solids from Research Organic/Inorganic Chemical Company and used without further purification.

7. Sodium Fluorosulfate. Sodium fluorosulfate was purchased from Research Organic/Inorganic Chemical Company and heated under vacuum before use. Purity was checked by Infrared analysis.

8. Potassium Dichromate. Potassium dichromate was purchased 
from Mallinckrodt Chemical Company and heated under vacuum before use.

9. Potassium Chromate. Potassium chromate was purchased from Mallinckrodt Chemical Company and heated under vacuum before use.

10. Cesium Chromate. Cesium chromate was purchased from Matheson Company and heated under vacuum before use.

11. Sodium Molybdate. Sodium molybdate was purchased from Mallinckrodt Chemical Company and purified by heating under vacuum. 12. Sodium Tungstate. Sodium tungstate was purchased from Mallinckrodt Chemical Company and purified by heating under vacuum. 13. Nitrogen. Dry nitrogen gas for the distillation of fluorosulfonic acid and use in some reactions to be discussed later, was obtained from a commercial cylinder from Airco and further dried by passing through concentrated sulfuric acid and a $\mathrm{CaCl}_{2}$ drying column. 
CHAPTER III

SYNTHESIS OF URANIUM FLUOROSULFATES

A. The Reaction of Fluorosulfonic Acid With Anhydrous Uranium Metal

1. Introduction. The nature of the green solution mentioned by Woolf (24) resulting from the action of uranium metal in fluorosulfonic acid was first investigated. It was thought that the green color of the solution was due to the production of the $U^{+4}$ species; however, this conclusion was only tentative as Woolf in a later paper (23) found that the same green solution was produced when alkali, alkaline - earth, and tin were dissolved in fluorosulfonic acid.

The following reaction was postulated as occurring:

$$
\mathrm{U}+4 \mathrm{HOSO}_{2} \mathrm{~F}=\mathrm{U}\left(\mathrm{OSO}_{2} \mathrm{~F}\right)_{4}+2 \mathrm{H}_{2}
$$

At a temperature of $60^{\circ}$ this reaction has been found to occur. However, the reaction of uranium metal with fluorosulfonic acid at an elevated temperature greater than $100^{\circ}$ seems to favor the formation of a pale green solid which is thought to be $U\left(\mathrm{SO}_{3} \mathrm{~F}\right)_{2}$.

\section{Experimental.}

a. Preparation. To 3.39 mmoles of uranium metal contained in a $100 \mathrm{~m} 1$ Pyrex bulb, 0.364 moles of fluorosulfonic acid were added via the $500 \mathrm{~m} 1$ storage vessel. The vessel was surrounded by a $-196^{\circ}$ bath and upon addition of the acid, the vessel was attached to the vacuum system and completely evacuated. The vesseI was then placed 
behind a safety shield and allowed to warm to room temperature. After 24 hours, the appearance of the first greenish color was noted. The vessel was allowed to stand for several days at room temperature and then placed in an oil bath at $60^{\circ}$ for one week to make sure that all the uranium metal had dissolved.

Periodically the vessel was taken out of the bath and attached to the vacuum system, and while at $-196^{\circ}$ evacuated to remove the hydrogen gas liberated and thereby drive the reaction to completion. After one week, the reaction was complete as noted by the disappearance of any unreacted uranium metal. The excess fluorosulfonic acid was then pumped away through a trap cooled to $-196^{\circ}$. The reaction vessel was first kept at room temperature then later heated to $65^{\circ}$ to remove the last traces of acid. After reaching constant weight $\left[3.39\right.$ moles of $\left.\mathrm{U}\left(\mathrm{SO}_{3} \mathrm{~F}\right)_{4}\right]$, the solid had the appearance of a very pale brownish green solid (decomposes at about $405^{\circ}$ producing what appears to be $\mathrm{SO}_{3}$ ).

The chemical analysis of this compound was in good agreement with the expected composition for the uranium (IV) fluorosulfate: U $37.5 \%$ (found $37.4 \%$ ); S $20.2 \%$ (found $20.2 \%$ ). However, the percentage of elemental fluorine was found to be lower than the calculated value, a finding that leads the author to believe that there may be some problem in analysis for fluorine in the presence of a very heavy metal such as uranium.

The Infrared spectrum and magnetic data were found to be in agreement with the uranium (IV) fluorosulfate obtained from the reaction of $\mathrm{UCl}_{4}$ and $\mathrm{S}_{2} \mathrm{O}_{6} \mathrm{~F}_{2}$, and will be discussed under a later heading. 
The reaction of uranium metal and fluorosulfonic acid was also carried out in a different manner at a much higher temperature; results seem to indicate formation of $\mathrm{U}\left(\mathrm{SO}_{3} \mathrm{~F}\right)_{2}$.

To 22.0 mmoles of uranium metal in a Pyrex glass bulb, 0.152 moles of $\mathrm{HOSO}_{2} \mathrm{~F}$ were added in a similar manner as described above. The bulb was evacuated at $-196^{\circ}$ and allowed to warm to room temperature. Instead of heating in the cloased vessel as before, the vessel was taken into a dry nitrogen box and opened to allow an atmosphere of nitrogen to enter the vessel. The vessel was then attached to a trap at $-78^{\circ}$ which in turn was attached to a mercury bubbler. The trap-bubbler system had previously been flushed with dry nitrogen. The vessel was opened and placed in an oil bath and the acid refluxed at $155^{\circ}$. The reaction was over in two hours forming a green solid in solution. The vessel was then closed and attached to the vacuum system and the excess acid removed as before at a temperature of $100^{\circ}$. The acid removal took several months, at which time the product [22.0 mmoles of $\left.\mathrm{U}\left(\mathrm{SO}_{3} \mathrm{~F}\right)_{2}\right]$ took on a final pale green color (does not melt up to $405^{\circ}$ ).

b. Chemical Analysis. The chemical analysis of this pale green solid are in fair agreement for the proposed composition of uranium (II) fluorosulfonate: U $54.6 \%$ (found $51.4 \%$ ); S $14.7 \%$ (found 15.1\%). Again, the fluorine analysis was low.

c. X-Ray Powder Photograph. X-ray powder spectra was taken of $U\left(\mathrm{SO}_{3} \mathrm{~F}\right)_{2}$ in order to ensure that all of the reactant $U$ metal was consumed and that the product was in fact different. The solid was transferred into the capillary in a dry nitrogen box. $x$-ray data confirmed that there was no unreacted $U$ metal present. The data 
are given in Table $I$ and give the $d$ values (in $\stackrel{\circ}{A}$ ) with only the intensities of strong (s), medium (m) and weak (w) given.

d. Infrared Spectra. The infrared spectrum $\left(\mathrm{cm}^{-1}\right)$ for the solid is given below with the relative intensities of very strong (vs), strong (s), medium (m), weak (w), very weak (vw), broad (b), shoulder (sh):

$$
\begin{aligned}
& 1620(w), 1325(\mathrm{sh}), 1255(\mathrm{sh}), 1180(\mathrm{~b}), 1075(\mathrm{sh}), \\
& 980(\mathrm{~m}), 910(\mathrm{w}), 855(\mathrm{sh}), 735(\mathrm{w}), 616(\mathrm{w}), 595(\mathrm{~m}), \\
& 570(\mathrm{w}), 430(\mathrm{~m}) .
\end{aligned}
$$

The spectrum is shown in Figure 2. Some probable assignments are: $1255 \mathrm{sh}, \mathrm{SO}_{3}$ asymmetric stretch (32); $1075 \mathrm{sh}$, S-0 symmetric stretch; $980 \mathrm{~m} \mathrm{SO}_{3}$ asymmetric stretch (53); $735 \mathrm{w}, \mathrm{S}-\mathrm{F}$ stretch (32); $616 \mathrm{w}$, S-O asymmetric stretch; $570 \mathrm{w}$, S-O symmetric deformation (32); $430 \mathrm{~m}, \mathrm{~s} 00$ bend (53). There is a great deal of cell attack in the region $1260-1000 \mathrm{~cm}^{-1}$ which makes this region difficult to resolve; this is a common problem in fluorosulfonate work (54).

\section{e.- Magnetic Susceptibility. Magnetic susceptibility}

measurements were run on the pale green solid in order to get an idea of how many unpaired electrons were present in the compound to help further characterize uranium in the +2 state.

Calculation of $\mu$ eff was carried by the equation (55):

$$
\text { Xunk }=\frac{\omega \text { unk }}{\omega \text { unk }} \cdot \frac{\omega \text { std }}{\omega \text { std }} \cdot \text { Xstd }
$$

a $4 \mathrm{~mm}$ O.D. Pyrex glass tube was used as the Gouy rod and filled with the sample in a dry nitrogen box.

The ground state of uranium metal is [Rn] $5 f^{3} 6 d^{\prime} 7 s^{2}$. Evidence has indicated (56) that two d electrons in some uranium +2 compounds 
TABLE I

X-RAY POWDER SPECTRA FOR U(OSO $\left.{ }_{2} \mathrm{~F}\right)_{2}$

\begin{tabular}{llll}
$\mathrm{d}, \AA$ & $\mathrm{I}_{\mathrm{o}}$ & $\mathrm{d}, \AA$ & $\mathrm{I}_{\mathrm{o}}$ \\
\hline 4.58 & $\mathrm{~s}$ & 1.71 & $\mathrm{w}$ \\
3.56 & $\mathrm{w}$ & 1.60 & $\mathrm{w}$ \\
3.14 & $\mathrm{~s}$ & 1.53 & $\mathrm{~m}$ \\
2.65 & $\mathrm{~s}$ & 1.48 & $\mathrm{w}$ \\
2.06 & $\mathrm{~s}$ & 1.38 & $\mathrm{~m}$ \\
1.94 & $\mathrm{~m}$ & 1.32 & $\mathrm{~m}$ \\
1.84 & $\mathrm{w}$ & 1.27 & $\mathrm{w}$ \\
1.74 & $\mathrm{~s}$ & &
\end{tabular}




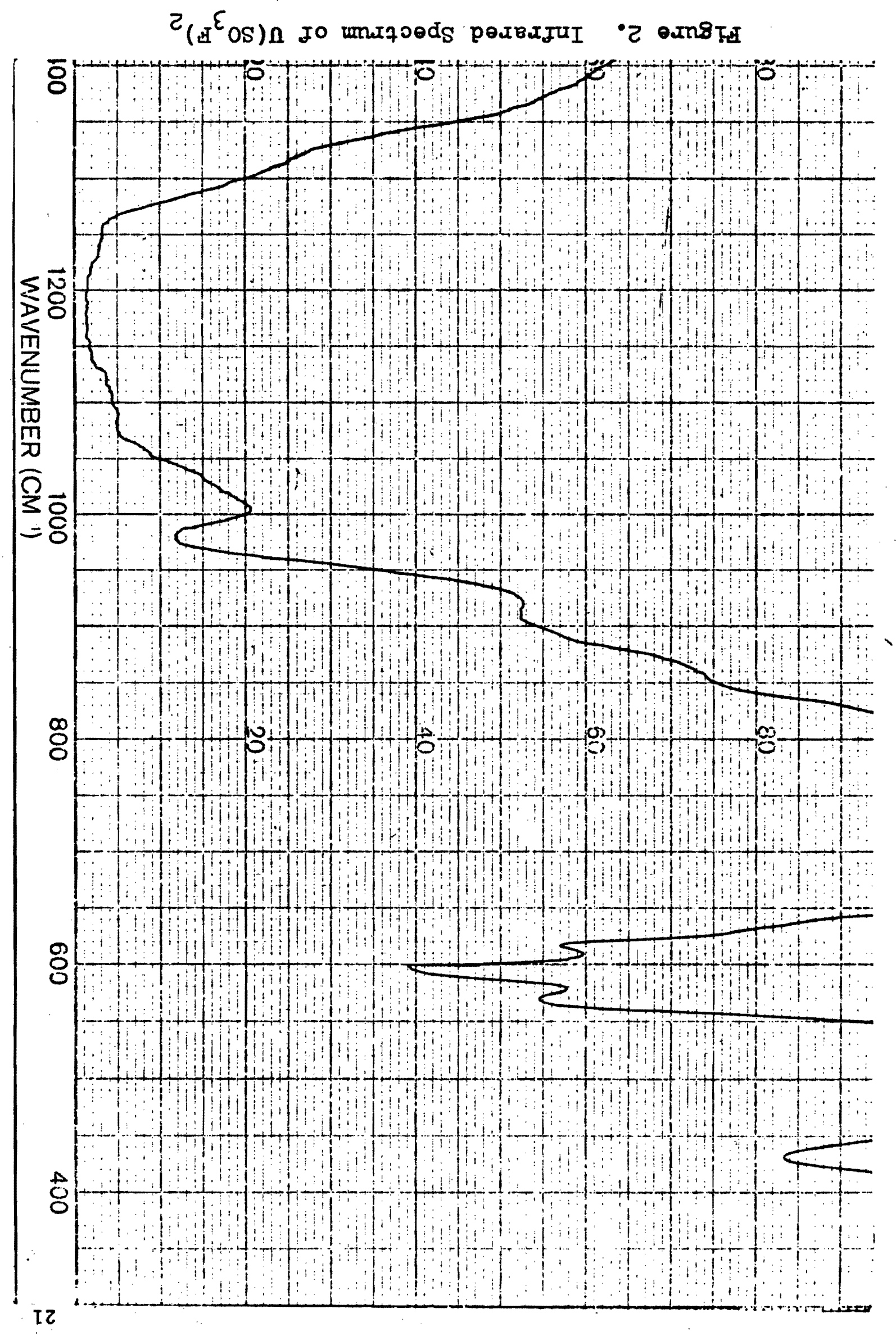


are used in strong metal-bonds; this fact has lead to the belief that $\mathrm{U}^{+2}$ has the structure [Rn] $6 \mathrm{~d}^{2} 7 \mathrm{~s}^{2}$, where the $5 \mathrm{f}$ electrons are removed first and the third is promoted to a close lying $6 \mathrm{~d}$ orbital. The ground state term symbol for this species would be ${ }^{3} F_{2}$ and the species would contain two unpaired electrons in the $6 \mathrm{~d}$ orbital.

Calculations using the Curie Law (57) yield a value of 2.81

B.M. compared to a theoretical value (spin only formula) of 2.83

B.M. or 1.63 B.M. (free ion moment) (58).

Data for the above calculation is given below:

Field off: wt. empty tube, $4.99379 \mathrm{~g}$; wt. of tube and calibrant, $6.42929 \mathrm{~g}$; wt. of tube and sample, $7.32827 \mathrm{~g}$.

Field on: wt. empty tube, $4.99245 \mathrm{~g}$; wt. of tube and calibrant, $6.46490 \mathrm{~g}$; wt. of tube and sample, $7.35388 \mathrm{~g}$.

B. Reaction of Peroxydisulfuryl Difluoride With Anhydrous Uranium Tetrachloride

1. Introduction. The reactions of anhydrous transition metal oxychlorides or chlorides has provided a good route for the production of transition metal fluorosulfates and oxyfluorosulfates. Rochat and Gard found that the chlorine was completely displaced in the reaction of $\mathrm{CrO}_{2} \mathrm{Cl}_{2}$ and $\mathrm{S}_{2} \mathrm{O}_{6} \mathrm{~F}_{2}$ (34):

$$
\mathrm{CrO}_{2} \mathrm{Cl}_{2}+\mathrm{S}_{2} \mathrm{O}_{6} \mathrm{~F}_{2}=\mathrm{CrO}_{2}\left(\mathrm{SO}_{3} \mathrm{~F}\right)_{2}+\mathrm{Cl}_{2}
$$

Lustig and Cady found that $\mathrm{SnCl}_{4}$ reacted with $\mathrm{S}_{2} \mathrm{O}_{6} \mathrm{~F}_{2}$ to yield $\mathrm{SnCl}\left(\mathrm{SO}_{3} \mathrm{~F}_{3}(30)\right.$.

In these reactions the central metal atom remains in its high oxidation state. These results suggest that uranium tetrachloride 
may react similarly. The reaction of $\mathrm{UCl}_{4}$ occurs readily at $60^{\circ}$ :

$$
\mathrm{UCl}_{4}+2 \mathrm{~S}_{2} \mathrm{O}_{6} \mathrm{~F}_{2}=\mathrm{U}\left(\mathrm{SO}_{3} \mathrm{~F}\right)_{4}+2 \mathrm{Cl}_{2}
$$

The product has the same tan color as the product from the reaction of uranium metal with fluorosulfonic acid. It is stable up to $405^{\circ}$ where it decomposes to a greenish solid and fumes.

\section{Experimenta1.}

a. Preparation. The preparation of $\mathrm{U}\left(\mathrm{SO}_{3} \mathrm{~F}\right)_{4}$ was carried out several times first with small amounts and later with larger amounts of $\mathrm{UCl}_{4}$ so that an accurate check of chlorine gas production could be found. A specific run that gave good results will be described. To 3.79 mmoles of anhydrous uranium tetrachloride contained in an $100 \mathrm{ml}$ Pyrex bulb, 19.5 moles of $\mathrm{S}_{2} \mathrm{O}_{6} \mathrm{~F}_{2}$ was vacuum distilled. The vessel was initially at $-196^{\circ}$ and upon addition of the peroxide was allowed to warm to room temperature behind a safety shield. Formation of the yellowish tan product occurs after several days of magnetically stirring the mixture via a Teflon-covered stirring bar contained in the vessel. It was necessary in all preparations of the product to use a rather larger excess of peroxide to thoroughly "wet" all of the solid $\mathrm{UCl}_{4^{-}}$. It was also necessary to have a good excess in order to manually "wash" down some of the unreacted UC1 4 from sides of the vessel due to the stirring-bar action. After completion of the reaction when the characteristic dark green color of $\mathrm{UCl}_{4}$ was no longer visible, the vessel was hooked to the vacuum system and the amount of chlorine gas produced was found by surrounding the vessel in a $-78^{\circ}$ bath and opening it to a closed system containing 
a preweighed evacuated weighing bulb in a $-196^{\circ}$ bath. It was necessary to close the vessel and allow it to come to room temperature several times to make sure that any trapped chlorine gas would be sure to transfer. The weight of chlorine gas found in the weighing bulb was $0.536 \mathrm{~g}$ (calculated $0.537 \mathrm{~g}$ ). Infrared analysis of the gas showed only background bands (no $\mathrm{S}_{2} \mathrm{O}_{6} \mathrm{~F}_{2}$ ).

The volatile peroxide was then removed by pumping through a $-196^{\circ}$ trap. The final product $\left[3.79\right.$ moles of $\left.U\left(\mathrm{SO}_{3} \mathrm{~F}\right)_{4}\right]$ is a very light tan solid of extremely fine grain.

b. Chemical Analysis. The chemical analysis for this light tan solid are in good agreement for the proposed stoichiometry: U $37.5 \%$ (found $38.6 \%$ ); S $20.2 \%$ (found $17.5 \%$ ); F $12.0 \%$ (found $14.0 \%$ ). The low values for sulfur and fluorine may be due to the heating of the productin order to drive off the last traces of the peroxide. Fluorosulfonates are not as thermally stable as sulfates (17) and some decomposition to $\mathrm{SO}_{3}$ and a uranium fluoride may have occurred (4):

$$
\mathrm{U}\left(\mathrm{SO}_{3} \mathrm{~F}\right)_{4}=\mathrm{UF}_{4}+4 \mathrm{SO}_{3}
$$

c. X-Ray Powder Photograph. X-ray powder spectra were taken of $\mathrm{U}\left(\mathrm{OSO}_{2} \mathrm{~F}\right)_{4}$ to ensure that all the uranium tetrachloride was consumed. The data are given in Table II and when compared to an $\mathrm{X}$-ray spectra of the $\mathrm{UCl}_{4}$ used confirm that no unreacted $\mathrm{UCl}_{4}$ remained.

d. Infrared Spectra. The infrared spectra are presented below and the spectrum shown in Figure 3:

1280 (s); 1071 (m); 920 (w), 880 (w); 733 (s); 580 (s); 479 (vw). 
The probable assignments are: $1280 \mathrm{~s}, \mathrm{SO}_{3}$ asymmetric stretch; $1071 \mathrm{~m}$, S-0 symmetric stretch; $920 \mathrm{w}, \mathrm{SO}_{3}$ asymetric stretch; $733 \mathrm{~s}, \mathrm{~S}-\mathrm{F}$ stretch; $580 \mathrm{~s}$, S-0 symmetric stretch.

e. Magnetic Susceptibility. The magnetic and spectral behavior of anhydrous transition metal fluorosulfates is fairly normal (59). Comparisons of the magnetic moment for $\beta-U_{2}$ (2.85 B.M.) have shown that the value is very close to the spin-only moment for two unpalred electrons (2.83 B.M.). From this Picon andFlahaut (60) assumed uranium to be in the tetravalent state, the two unpaired electrons being in the 6d orbital. Other work by Rudorff and Menger (61) on uranium (V) compounds have shown that eff fits more closely to the value one would expect for the unpaired electron if it were in the $6 \mathrm{~d}$ orbital rather than the $5 f$.

Calculations using the Curie Law yield a value of 2.00 B.M. for the light $\tan$ solid $\mathrm{U}\left(\mathrm{SO}_{3} \mathrm{~F}\right)_{4^{\circ}}$. This value falls between the free ion moment (1.63 B.M.) and the spin-only moment (2.83 B.M.) and has been observed to be the case also in a number of uranium chalcogenides (58). Theoretical calculations for the free ion moment for the $5 f^{2}$ configuration yield a moment of $3.57 \mathrm{~B} . \mathrm{M}$. and is much too high from the observed results.

Data for the above calculations is given below:

Fleld off: wt. empty tube, $4.99386 \mathrm{~g}$; wt. of tube and calibrant, $6.43586 \mathrm{~g}$; wt. of tube and sample, 6.19019 g.

Field on: wt. empty tube, 4.99251; wt. of tube and calibratn, $6.47665 \mathrm{~g}$; wt. of tube and sample, $6.19608 \mathrm{~g}$. 


\section{TABLE II}

$X$-RAY POWDER SPECTRA FOR U(OSO 2$)_{4}$

\begin{tabular}{llll}
$\mathrm{d}, \AA$ & $\mathrm{I}_{\mathrm{o}}$ & $\mathrm{d}, \AA$ & $\mathrm{I}_{\mathrm{o}}$ \\
\hline 4.73 & $\mathrm{~s}$ & 1.98 & $\mathrm{~m}$ \\
4.10 & $\mathrm{~m}$ & 1.83 & $\mathrm{w}$ \\
3.64 & $\mathrm{~m}$ & 1.79 & $\mathrm{~s}$ \\
3.22 & $\mathrm{~s}$ & 1.73 & $\mathrm{~m}$ \\
3.09 & $\mathrm{w}$ & 1.52 & $\mathrm{w}$ \\
2.96 & $\mathrm{w}$ & 1.43 & $\mathrm{w}$ \\
2.73 & $\mathrm{~s}$ & 1.22 & $\mathrm{w}$ \\
2.12 & $\mathrm{~m}$ & 1.12 & $\mathrm{w}$
\end{tabular}




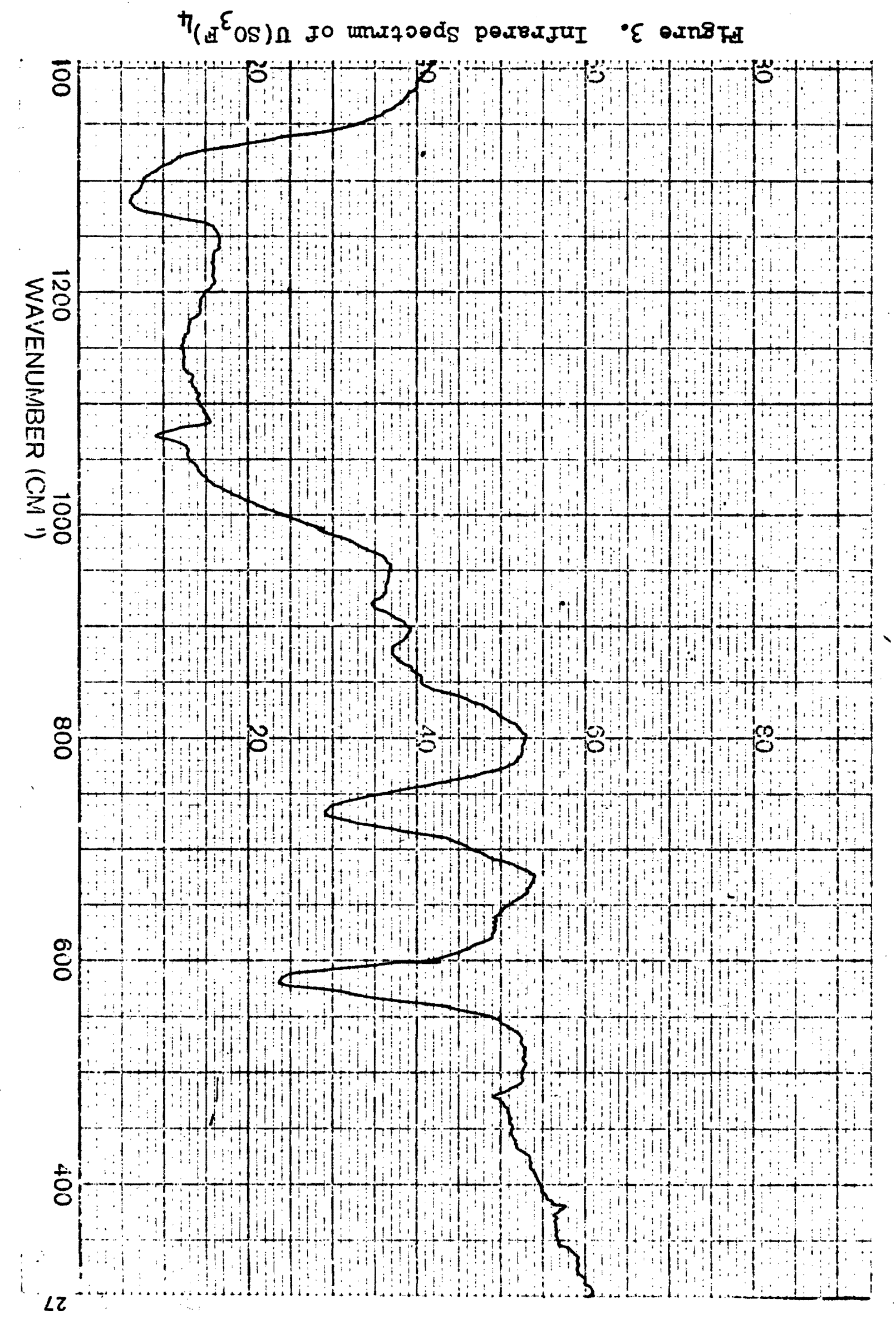


c. Other Reactions Involving Peroxydisulfuryl Difluoride

1. Behavior of $\mathrm{S}_{2} \mathrm{O}_{6} \mathrm{~F}_{2}$ on $\mathrm{UF}_{4^{\circ}}$ The reaction of uranium tetrafluoride with peroxydisulfuryl difluoride was studied in order to prepare novel uranium (VI) fluorosulfate fluorides.

To 5.62 moles of uranium tetrafluoride contained in a $100 \mathrm{ml}$ Pyrex reaction vessel, 42.0 moles of $\mathrm{S}_{2} \mathrm{O}_{6} \mathrm{~F}_{2}$ was added. The vessel initially at $-196^{\circ}$ and upon the addition of $S_{2}{ }_{0} F_{2}$ was warmed to room temperature. Initially there was no reaction, however, after an hour the limegreen $\mathrm{UF}_{4}$ had started to turn cream-green. The reaction was allowed to mix for two weeks via a Teflon covered stirring bar at room temperature. The reaction was checked for non-volatile materials hooking the vessel at $-78^{\circ}$ to the vacuum system and noting any pressure. No pressure was noted. The reaction was deemed complete by the absence of any unreacted $\mathrm{UF}_{4}$ (limegreen). The reaction mixture was then pumped on at room temperature through a trap held at $-196^{\circ}$ until constant weight loss was obtained (about one week). The weight of product (5.62 mmoles) corresponded to the formation of $\mathrm{UF}_{4}\left(\mathrm{SO}_{3} \mathrm{~F}\right)_{2}$. Examination of the trap material showed the presence of $\mathrm{SIF}_{4}$ and $\mathrm{S}_{2} \mathrm{O}_{6} \mathrm{~F}_{2}$.

Chemical analysis of the yellow solid $\mathrm{UF}_{4}\left(\mathrm{SO}_{3} \mathrm{~F}\right)_{2}$ were in good agreement for the proposed compound: U 46.5\% (found $47.5 \%$ ); $\mathrm{s} 12.5 \%$ (found 14.9\%); F 22.3\% (found 19.1\%). Melting point of the solid was at $210^{\circ}$.

The infrared spectra shown in Figure 4 contain the following absorptions $\left(\mathrm{cm}^{-1}\right)$ : $1285 \mathrm{~s}, \mathrm{~s}-0$ asymmetric stretch; $1070 \mathrm{~m}, \mathrm{~s}-0$ symmetric stretch; $705 \mathrm{~m}$, S-F stretch; $620 \mathrm{sh}$, S-0 asymetric deformation; $575 \mathrm{~m}$, s-O symmetric deformation (32). 


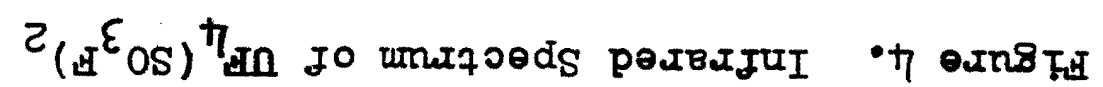

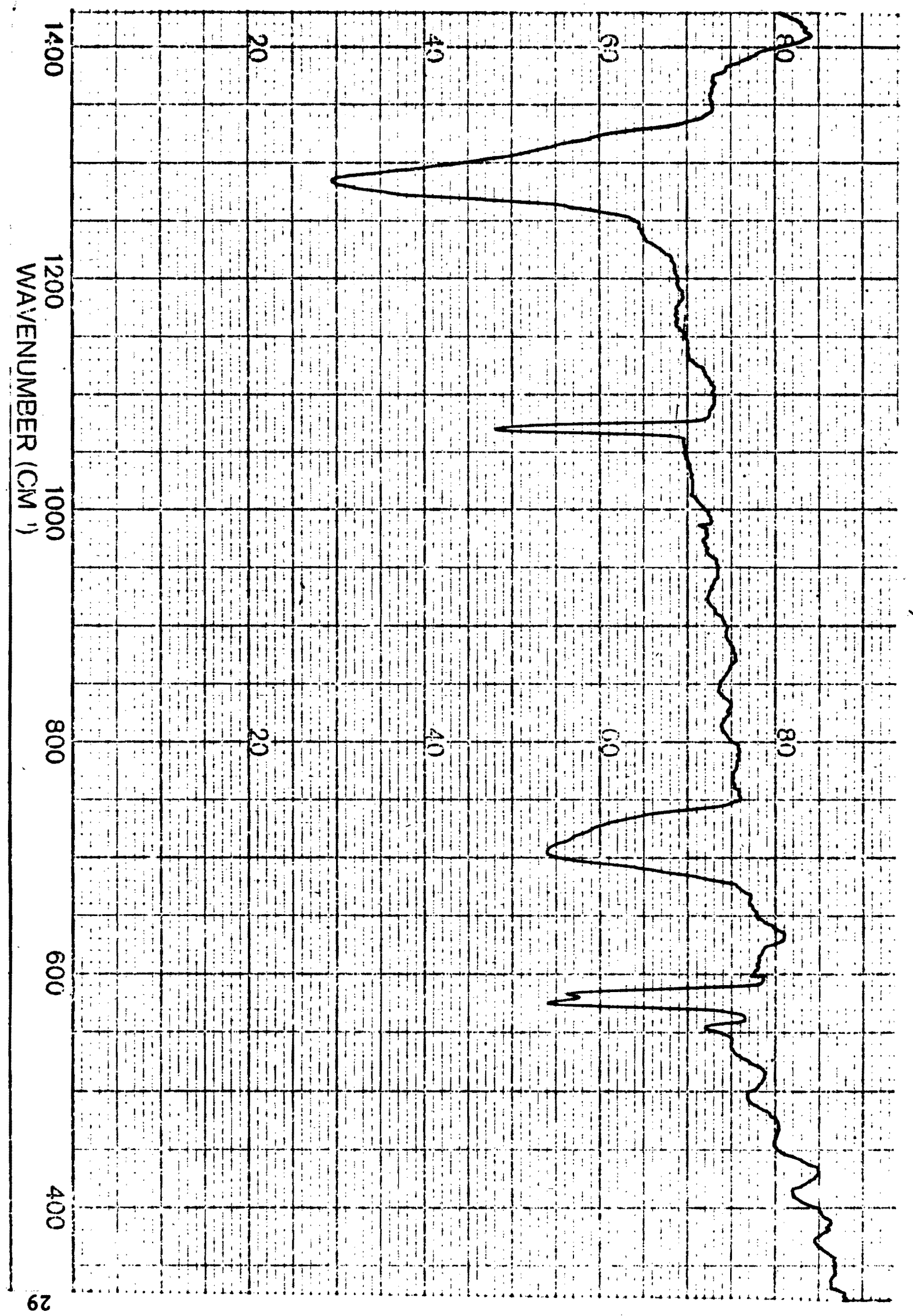


2. Behavior of $S_{2}{ }_{6} \underline{F}_{2}$ on Uranium Metal. The behavior of peroxydisulfuryl difluoride on uranium metal was studied to determine if it was possible to oxidize uranium in a similar manner as fluorosulfonic acid did and produce the fluorosulfate or the oxyfluorosulfate,

$$
\mathrm{U}+\mathrm{n} \mathrm{S}_{2} \mathrm{O}_{6} \mathrm{~F}_{2}=\mathrm{U}\left(\mathrm{SO}_{2} \mathrm{~F}\right)_{2 \mathrm{n}} \text { or } \mathrm{UO}\left(\mathrm{SO}_{3} \mathrm{~F}\right)_{2 \mathrm{n}}
$$

Peroxydisulfuryl difluoride (34.0 moles) was distilled on to 2.31 moles of uranium metal in a $100 \mathrm{ml}$ reaction bulb held at $-196^{\circ}$. The mixture was allowed to warm to room temperature. It was necessary to heat the mixture to $60^{\circ}$ in order to initiate a reaction. After one week of heating, the reaction was complete as evidenced by the disappearance of any unreacted uranium metal. A dark green solid was produced. A check for production of oxygen (opening vessel at $-196^{\circ}$ to closed line) showed none. The excess peroxide was drawn off the solid through a trap held at $-196^{\circ}$ on the vacuum system. Analysis of the trap material showed only $\mathrm{S}_{2} \mathrm{O}_{6} \mathrm{~F}_{2}$. The solid was pumped for several weeks to reach a constant weight $[2.31$ moles of $\left.\mathrm{U}\left(\mathrm{SO}_{3} \mathrm{~F}\right)_{3}\right]$. The solid was green and does not change appearance up to $405^{\circ}$.

Chemical analysis of the green solid agreed well with the expected values: U $44.5 \%$ (found $46.8 \%$ ); S $17.9 \%(12.0 \%$ ); F $10.7 \%$ (found $11.0 \%$ ).

The Infrared spectra shows the following absorptions $\left(\mathrm{cm}^{-1}\right)$ : $1274 \mathrm{~s}$, S-0 asymmetric stretch; $1075 \mathrm{~m}$, S-0 symmetric stretch; $728 \mathrm{~m}$, S-F stretch; $575 \mathrm{w}$, S-0 symmetric deformation. 
D. Reactions Involving Uranium (IV) Fluorosulfate as a Reactant

1. Reaction of $\mathrm{CH}_{3} \mathrm{CN}$ With $\mathrm{U}\left(\mathrm{SO}_{3} \mathrm{~F}_{4} 4^{\circ}\right.$ The reaction of uranium (IV) fluorosulfate with acetonitrile was studied to determine the coordinating ability of uranium (IV) with a ligand whose donor atom is nitrogen. Recent reactions (62) by J. Selbin on uranium (V) compounds have shown the coordinating ability of uranium to extend not only to nitrogen containing donors but also to ligands whose donor at oms are phosphorus, arsenic, bismuth, sulfur, selenium and tellurium. Acetonitrile (0.129 moles) was distilled onto 0.953 moles of $\mathrm{U}\left(\mathrm{SO}_{3} \mathrm{~F}\right)_{4}$ in a $200 \mathrm{ml}$ reaction bulb held at $-196^{\circ}$. The mixture was allowed to come to room temperature. Initially a green solution resulted and after three days the reaction was heated at $60^{\circ}$ to ensure complete reaction. The formation of a light green solid resulted. The excess $\mathrm{CH}_{3} \mathrm{CN}$ was drawn off through a trap held at $-196^{\circ}$. Examination of the trap contents showed only acetonitrile present. After 24 hours of pumping at $50^{\circ}$ all the excess acetonitrile had been removed and the final light green solid (no melting point up to $400^{\circ}$ ) corresponded final light green solid (no melting point up to $400^{\circ}$ ) corresponded to a $3: 1$ adduct $\left[0.953\right.$ mmoles of $\left.\mathrm{U}\left(\mathrm{SO}_{3} \mathrm{~F}\right)_{4} \cdot 3 \mathrm{CH}_{3} \mathrm{CN}\right]$.

$$
\mathrm{U}\left(\mathrm{SO}_{3} \mathrm{~F}\right)_{4}+3 \mathrm{CH}_{3} \mathrm{CN}=\mathrm{U}\left(\mathrm{SO}_{3} \mathrm{~F}\right)_{4} \cdot 3 \mathrm{CH}_{3} \mathrm{CN}
$$

An $x$-ray powder spectrum of this solid showed it to be amorphous. Chemlcal analysis data are given below:

U $31.4 \%$ (found $32.5 \%$ ); S $16.9 \%$ (found $16.0 \%$ );

F $10.0 \%$ (found $9.5 \%$ ); C $9.5 \%$ (found $9.9 \%$ );

H $1.2 \%$ (found $1.4 \%$ ); N $5.6 \%$ (found $5.7 \%$ ). 
The infrared spectrum shown in Figure 5 is rather complex due tothe overlap of bands coming from both the $\mathrm{U}\left(\mathrm{OSO}_{3} \mathrm{~F}\right)_{4}$ and $\mathrm{CH}_{3} \mathrm{CN}$ groups. One can however distinguish individual absorptions arising from both compounds: 2245 sh, -CN stretch; $1410 \mathrm{w},-$ CN stretch; $1374 \mathrm{w},-$ CN stretch; 1280 b, S-0 stretch; 1080 sh, S-0 stretch; 1036 b, -CN stretch; 945 sh, CN stretch; 870 w, S-F stretch; 735 s, S-F stretch; $575 \mathrm{~m}$, S-0 stretch.

2. Reaction of $\mathrm{U}\left(\mathrm{SO}_{3} \mathrm{~F}_{4}{ }_{4}\right.$ With $\mathrm{NaSO}_{3} \mathrm{~F}$. The reaction of uranium (IV) fluorosulfate with sodium fluorosulfate in fluorofulfonic acid was carried out to note the behavior of the uranium compound towards the alkali fluorosulfate. Sodium fluorosulfate dissolves as a fully dissociated electrolyte in $\mathrm{HOSO}_{2} \mathrm{~F}(63)$ :

$$
\mathrm{NaSO}_{3} \mathrm{~F} \longrightarrow \mathrm{Na}^{+}+\mathrm{SO}_{3} \mathrm{~F}^{-}
$$

The compound therefore behaves as a strong base in this solvent since it produces the $\mathrm{SO}_{3} \mathrm{~F}^{-}$ion. Uranium (IV) fluorosulfate should therefore act as an acid in this system yielding a salt, $\mathrm{Na}_{2}\left[\mathrm{U}\left(\mathrm{SO}_{3} \mathrm{~F}\right)_{6}\right]$ :

$$
\mathrm{U}\left(\mathrm{SO}_{3} \mathrm{~F}\right)_{4}+2 \mathrm{NaSO}_{3} \mathrm{~F} \stackrel{\mathrm{HSO}_{3} \mathrm{~F}}{\longrightarrow} \mathrm{Na}_{2}\left[\mathrm{U}\left(\mathrm{SO}_{3} \mathrm{~F}\right)_{6}\right]
$$

To a 1:2 mole ratio of $\mathrm{U}\left(\mathrm{SO}_{3} \mathrm{~F}\right)_{4}$ and $\mathrm{NaSO}_{3} \mathrm{~F}\left(1.44\right.$ mole $\left.\mathrm{U}\left(\mathrm{SO}_{3} \mathrm{~F}\right)_{4}\right)$ contained in a $100 \mathrm{ml}$ Pyrex reaction vessel at $-196^{\circ}, 0.188$ moles of $\mathrm{HSO}_{3} \mathrm{~F}$ was added via the fluorosulfonic acid storage vessel. The vessel was re-evacuated to make certain no air was inside, then allowed to warm to room temperature. Initially a greenish solid began to form. The mixture was heated at $60^{\circ}$ for one week. The excess $\mathrm{HSO}_{3} \mathrm{~F}$ was pumped away through a trap held at $-196^{\circ}$. The vessel was heated at $70^{\circ}$ then $120^{\circ}$ to drive off the acid which comes 


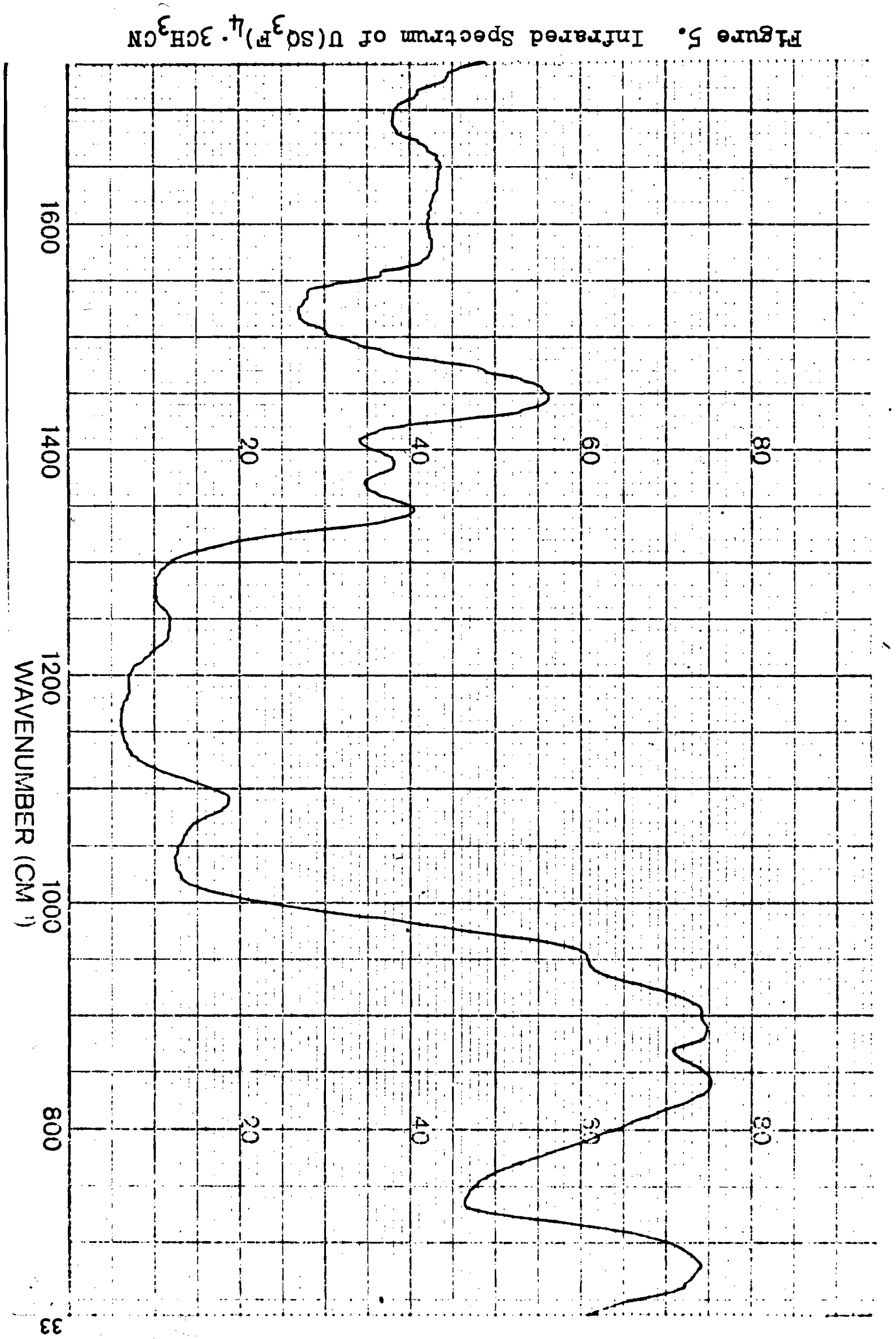


which comes off very slowly. After one week the weight of the light green product indicated that all the acid had been removed. The solid [1.44 mmoles of $\mathrm{Na}_{2} \mathrm{U}\left(\mathrm{SO}_{3} \mathrm{~F}\right)_{6}$ ] does not melt up to $400^{\circ}$. The $x$-ray powder spectrum of the solid is shown in Table III. Comparisons with the $\mathrm{U}\left(\mathrm{SO}_{3} \mathrm{~F}\right)_{4}$ and $\mathrm{NaSO}_{3} \mathrm{~F}$ spectra confirms that both reactants were completely used.

Chemical analysis of the compound as $\mathrm{Na}_{2}\left[\mathrm{U}\left(\mathrm{SO}_{3} \mathrm{~F}\right)_{6}\right]$ yielded the following results: S $21.8 \%$ (found $17.5 \%$ ); F $13.0 \%$ (found $9.6 \%$ ).

The infrared spectrum is shown in Figure 6 . Very recently (1973), Yeats and Aubke have synthesized the hexakis (fluorosulfato) stannate (IV) ion (64). Their proposed assignments were used to make tentative assignments on the following absorptions $\left(\mathrm{cm}^{-1}\right)$ : $1340 \mathrm{sh}, \mathrm{SO}_{2}$ asymmetric stretch; $1190 \mathrm{~b}, \mathrm{SO}_{2}$ symmetric stretch; 1045 sh, $0-\mathrm{SO}_{2} \mathrm{~F}$ stretch; $808 \mathrm{~s}, \mathrm{~S}-\mathrm{F}$ stretch; $560 \mathrm{~s}, \mathrm{SO}_{2}$ rock. 


\section{TABLE III}

X-RAY POWDER SPECTRA FOR $\mathrm{Na}_{2}\left[\mathrm{U}\left(\mathrm{SO}_{3} \mathrm{~F}\right)_{6}\right]$

\begin{tabular}{llll}
$\mathrm{d}, \AA$ & $\mathrm{I}_{\mathrm{o}}$ & $\mathrm{d}, \AA \mathrm{A}$ & $\mathrm{I}_{\mathrm{o}}$ \\
\hline 8.12 & $\mathrm{~s}$ & 2.87 & w \\
4.72 & $\mathrm{~s}$ & 2.72 & $\mathrm{~s}$ \\
4.12 & w & 2.11 & $\mathrm{~s}$ \\
3.66 & $\mathrm{~s}$ & 1.98 & $\mathrm{~s}$ \\
3.34 & $\mathrm{~s}$ & 1.78 & $\mathrm{~s}$ \\
3.03 & w & &
\end{tabular}




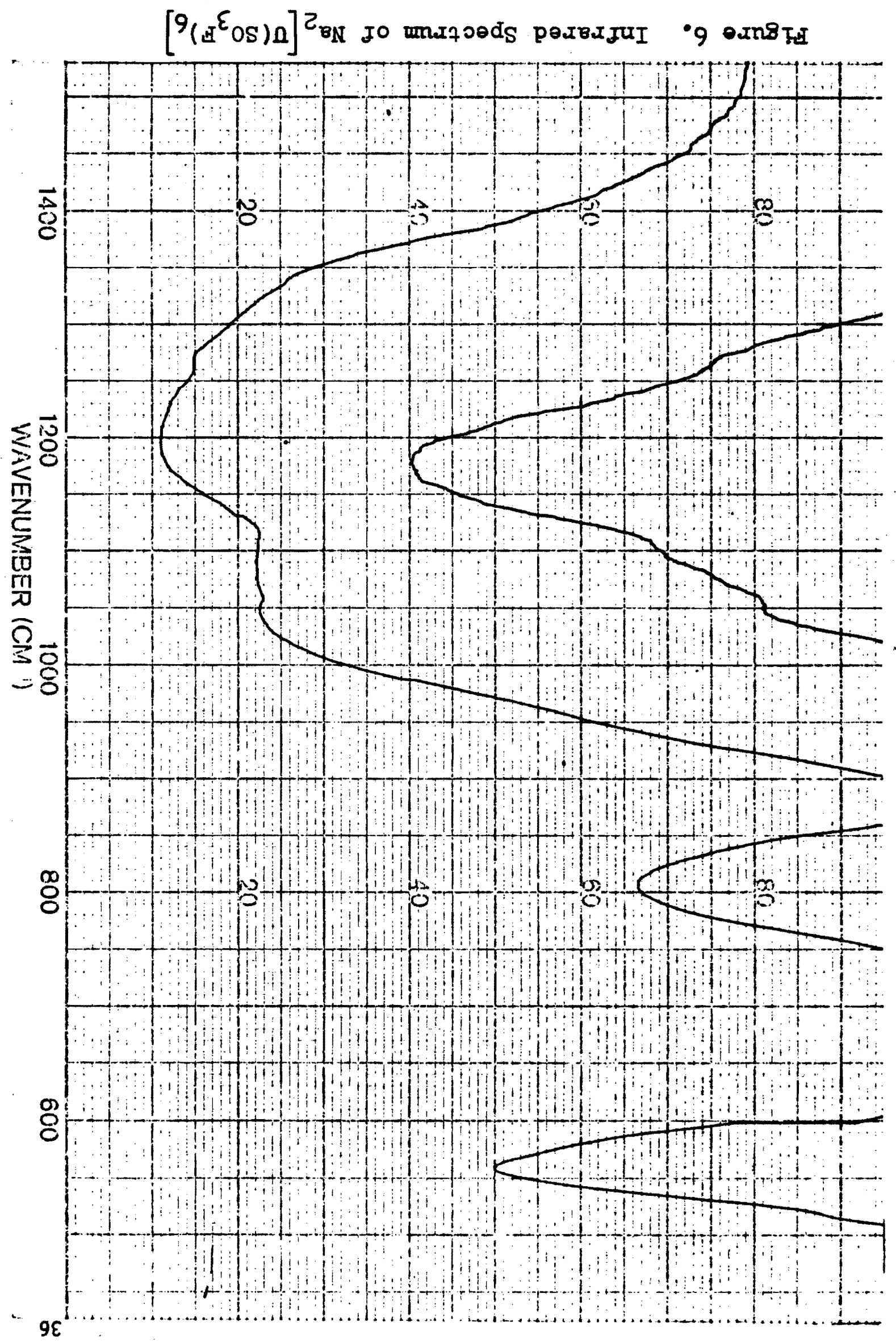


CHAPTER IV

\section{REACTIONS OF GROUP VI B METAL OXIDE SALTS WITH FLUORINATED ANHYDRIDES}

A. Reaction of $\mu$ - oxo-bis (phosphoryl difluoride) With Group VI B Metal Oxide Salts

1. Introduction. The addition of the fluorinated anhydride $\left(\mathrm{CF}_{3} \mathrm{CO}\right)_{2} \mathrm{O}$ across the chromium oxygen multiple bond (47).

$$
\mathrm{K}_{2} \mathrm{Cr}_{2} \mathrm{O}_{7}+3\left(\mathrm{CF}_{3} \mathrm{CO}\right)_{2} \mathrm{O}=2 \mathrm{KCrO}_{2}\left(\mathrm{CF}_{3} \mathrm{COO}\right)_{3}
$$

and of $\left(\mathrm{CF}_{3} \mathrm{CO}\right)_{2} \mathrm{O}$ with sodium molybdate,

$$
\mathrm{Na}_{2} \mathrm{MOO}_{4}+2\left(\mathrm{CF}_{3} \mathrm{CO}\right)_{2} \mathrm{O}=\mathrm{Na}_{2} \mathrm{MOO}_{2}\left(\mathrm{CF}_{3} \mathrm{COO}\right)_{4}
$$

suggest that $\mathrm{P}_{2} \mathrm{O}_{3} \mathrm{~F}_{4}$ may react similarly. Preliminary work by $S$. Brown of this laboratory has yielded the compound $\mathrm{K}_{2} \mathrm{CrO}_{2}\left(\mathrm{PO}_{2} \mathrm{~F}_{2}\right)_{4}$ from reaction of potassium chromate and $\mu$ - oxo-bis(phosphoryl difluoride):

$$
\mathrm{K}_{2} \mathrm{CrO}_{4}+2 \mathrm{P}_{2} \mathrm{O}_{3} \mathrm{~F}_{4}=\mathrm{K}_{2} \mathrm{CrO}_{2}\left(\mathrm{PO}_{2} \mathrm{~F}_{2}\right)_{4}
$$

It is rather surprising that fluoroanhydrides will effectively add across the $M=0$ multiple bond while hydrocarbon anhydrides will not. A mechanism (47) has been proposed for the addition of $\left(\mathrm{CF}_{3} \mathrm{CO}_{2}\right)_{2} \mathrm{O}$ and $\left(\mathrm{C}_{3} \mathrm{~F}_{7} \mathrm{CO}\right)_{2} \mathrm{O}$ across group VI B multiple bonds and may be extended to $\mathrm{P}_{2} \mathrm{O}_{3} \mathrm{~F}_{4}$. The possible pathway is: 


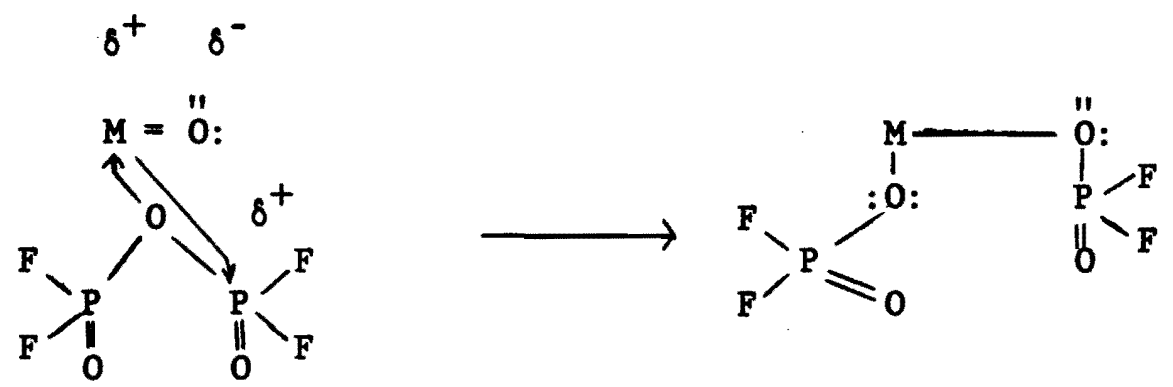

The fluorine atoms induces a partial positive charge on the phosphorus atom which make possible the interaction with the pi electrons in the M=0 linkage.

It was found that addition of $\mathrm{P}_{2} \mathrm{O}_{3} \mathrm{~F}_{4}$ to the group VI B oxide salts produced the difluorophosphate in the manner expected. The following reactions were carried out:

$$
\begin{aligned}
& \mathrm{R}_{2} \mathrm{Cr}_{2} \mathrm{O}_{7}+5 \mathrm{P}_{2} \mathrm{O}_{3} \mathrm{~F}_{4}=2\left[\mathrm{KCrO}_{2}\left(\mathrm{PO}_{2} \mathrm{~F}_{2}\right)_{3} \cdot \mathrm{P}_{2} \mathrm{O}_{3} \mathrm{~F}_{4}\right] \\
& \mathrm{Cs}_{2} \mathrm{CrO}_{4}+2 \mathrm{P}_{2} \mathrm{O}_{3} \mathrm{~F}_{4}=\mathrm{Cs}_{2} \mathrm{CrO}_{2}\left(\mathrm{PO}_{2} \mathrm{~F}_{2}\right)_{4} \\
& \mathrm{Na}_{2} \mathrm{MoO}_{4}+2 \mathrm{P}_{2} \mathrm{O}_{3} \mathrm{~F}_{4}=\mathrm{Na}_{2} \mathrm{MoO}_{2}\left(\mathrm{PO}_{2} \mathrm{~F}_{2}\right)_{4} \\
& \mathrm{Na}_{2} \mathrm{WO}_{4}+2 \mathrm{P}_{2} \mathrm{O}_{3} \mathrm{~F}_{4}=\mathrm{Na}_{2} \mathrm{WO}_{2}\left(\mathrm{PO}_{2} \mathrm{~F}_{2}\right)_{4}
\end{aligned}
$$

The new difluorophosphates are soluble in excess $\mathrm{P}_{2} \mathrm{O}_{3} \mathrm{~F}_{4}$ and melt around $150^{\circ}$. All compounds gave an amorphous $x-r$ ay powder spectrum.

\section{Experimental.}

a. Preparations. The same general method was used for all these reactions. The reaction vessels (Pyrex glass) used had a volume of $100 \mathrm{ml}$ and were equipped with a Kontes Teflon stopcock and a Teflon-covered stirring bar.

The metal oxide salt was transferred to the vessel then dried at $100^{\circ}$ under vacuum. Excess $\mu$-oxo-bis (phosphoryl difluoride), 
$\mathrm{P}_{2} \mathrm{O}_{3} \mathrm{~F}_{4}$, was then vacuum distilled into the reaction vessel held at $-196^{\circ}$. The mixture was then allowed to come to room temperature and was magnetically stirred at room temperature (or $60^{\circ}$ ).

After the reaction was complete, the excess $\mathrm{P}_{2} \mathrm{O}_{3} \mathrm{~F}_{4}$ was removed by pumping through a trap held at $-196^{\circ}$. The solid was then pumped till constant weight was achieved. Analysis of the trap material showed only $\mathrm{P}_{2} \mathrm{O}_{3} \mathrm{~F}_{4}$ and a small amount of HOPOF 2 present.

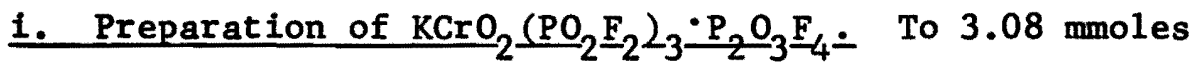
of $\mathrm{K}_{2} \mathrm{Cr}_{2} \mathrm{O}_{7}, 40.6$ mmoles of $\mathrm{P}_{2} \mathrm{O}_{3} \mathrm{~F}_{4}$ was added. Initially a red-brown solid was noted and after two days a dark brown solution resulted. The vessel was pumped on for two days at room temperature, but it was necessary to heat the product at $50^{\circ}$ for three additional days to completely remove all of the $\mathrm{P}_{2} \mathrm{O}_{3} \mathrm{~F}_{4}$. As it was, however, weights indicate the coordination of one more of $\mathrm{P}_{2} \mathrm{O}_{3} \mathrm{~F}_{4}$ to the expected compound [3.08 moles of $\mathrm{KCrO}_{2}\left(\mathrm{PO}_{2} \mathrm{~F}_{2}\right)_{3} \cdot \mathrm{P}_{2} \mathrm{O}_{3} \mathrm{~F}_{4}$ ]. The compound was light brown In color and decomposes at $300^{\circ}$ to a green solid.

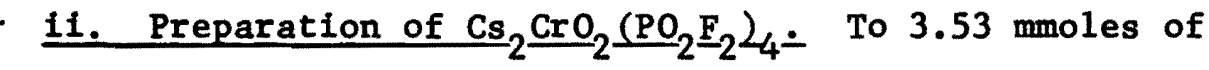
$\mathrm{Cs}_{2} \mathrm{CrO}_{4}, 54.9$ mmoles of $\mathrm{P}_{2} \mathrm{O}_{3} \mathrm{~F}_{4}$ was added. An immediate darkening of the mixture occurred upon warming to room temperature and after one hour reaction was deemed complete. A goldish brown solid results. It was necessary to pump on reaction product for four weeks at room temperature to remove the last traces of the anhydride. Weight [3.53 moles] corresponded to $\mathrm{Cs}_{2} \mathrm{CrO}_{2}\left(\mathrm{PO}_{2} \mathrm{~F}_{2}\right)_{4} \cdot 0.21 \mathrm{P}_{2} \mathrm{O}_{3} \mathrm{~F}_{4}$. The compound melts at $165^{\circ}$.

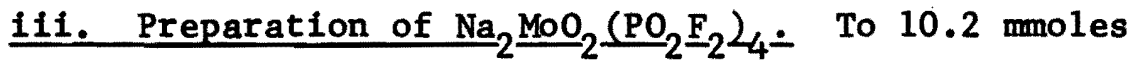
of $\mathrm{Na}_{2} \mathrm{MoO}_{4}, 68.8$ mmoles of $\mathrm{P}_{2} \mathrm{O}_{3} \mathrm{~F}_{4}$ was added. Initially no reaction was visible. Upon heating the mixture at $45^{\circ}$ a clear syrupy solution 
results after four hours. Initial pumping of the solution at room temperature and then at $60^{\circ}$ yielded a clear crystalline solid (resembles broken glass). Heating at $95^{\circ}$ for two weeks, then at $125^{\circ}$ for five days was required for complete removal of the anhydride. The compound $\left[10.2\right.$ moles of $\mathrm{Na}_{2} \mathrm{MoO}_{2}\left(\mathrm{PO}_{2} \mathrm{~F}_{2}\right)_{4}$ ] has a white crystalline appearance, although it gives no $x$-ray powder spectra. It fuses at $128^{\circ}$ and melts at $148-153^{\circ}$.

iv. Preparation of $\left.\mathrm{Na}_{2} \mathrm{WO}_{2} \mathrm{PO}_{2} \underline{\mathrm{F}}_{2}\right)_{4}-$ To 8.68 moles of $\mathrm{Na}_{2} \mathrm{WO}_{4}, 38.5$ moles of $\mathrm{P}_{2} \mathrm{O}_{3} \mathrm{~F}_{4}$ was added. Heating to $65^{\circ}$ was necessary to start reaction which yields a white fine powder in three hours. Complete reaction required additional heating for one week. The excess $\mathrm{P}_{2} \mathrm{O}_{3} \mathrm{~F}_{4}$ was removed from the solid while the vessel was held at $60^{\circ}$ for two weeks, then $90^{\circ}$ for an additional one week. The white powder [8.68 moles of $\mathrm{Na}_{2} \mathrm{WO}_{2}\left(\mathrm{PO}_{2} \mathrm{~F}_{2}\right)_{4}$ ] fuses at $123^{\circ}$ and melts at $148-151^{\circ}$.

b. Chemical Analysis. The compounds were analyzed by Beller Microanalytical Laboratory (see Physical Methods, Chapter II). The results are shown in Table IV.

c. Infrared Spectra. The infrared spectra for the difluorophosphates are listed in Table V. The spectra are shown in Figures 7-10. Al1 show the strong asymmetric $\mathrm{PO}_{2}$ stretch at 1200 to $1300 \mathrm{~cm}^{-1}$ (40), also the symetric $\mathrm{PO}_{2}$ stretch at 1130 to $1134 \mathrm{~cm}^{-1}$ (41). Other probable assignments are: $905-940 \mathrm{~cm}^{-1}$, asymmetric $\mathrm{PF}_{2}$ stretch; 818$890 \mathrm{~cm}^{-1}$, symmetric $\mathrm{PF}_{2}$ stretch; $465-500 \mathrm{~cm}^{-1}$, POF rock (40).

The asymetric $\mathrm{PO}_{2}$ stretch is at a lower frequency than would usually be expected $\left(1330 \mathrm{~cm}^{-1}\right)$ due to the tendency of larger cations, where interionic interactions are weaker, to have lower stretching 


\section{TABLE IV}

ANALYTICAL DATA FOR DIFLUOROPHOSPHATES

\begin{tabular}{|c|c|c|c|c|c|c|}
\hline Compound & $\begin{array}{r}\text { Me } \\
w t \\
\text { Expt } 1 \\
\end{array}$ & $\begin{array}{l}1 \\
\% \\
\text { Calc. }\end{array}$ & $\begin{array}{r}w \\
\text { Expt1 } \\
\end{array}$ & $\begin{array}{l}\% \\
\text { Calc. }\end{array}$ & Expt 1 & $\begin{array}{l}\% \\
\text { Calc. } \\
\end{array}$ \\
\hline $\mathrm{KCrO}_{2}\left(\mathrm{PO}_{2} \mathrm{~F}_{2}\right)_{3} \cdot \mathrm{P}_{2} \mathrm{O}_{3} \mathrm{~F}_{4}$ & 8.7 & 8.5 & 27.4 & 25.3 & 27.3 & 31.0 \\
\hline $\mathrm{Cs}_{2} \mathrm{CrO}_{2}\left(\mathrm{PO}_{2} \mathrm{~F}_{2}\right)_{4}$ & 6.5 & 6.5 & 18.3 & 17.4 & 21.9 & 21.2 \\
\hline $\mathrm{Na}_{2} \mathrm{MoO}_{2}\left(\mathrm{PO}_{2} \mathrm{~F}_{2}\right)_{4}$ & & & 23.6 & 22.1 & & \\
\hline $\mathrm{Na}_{2} \mathrm{WO}_{2}\left(\mathrm{PO}_{2} \mathrm{~F}_{2}\right)_{4}$ & & & 21.2 & 19.2 & & \\
\hline
\end{tabular}




\section{TABLE V}

INFRARED ABSORPTION BANDS FOR DIFLUOROPHOSPHATES

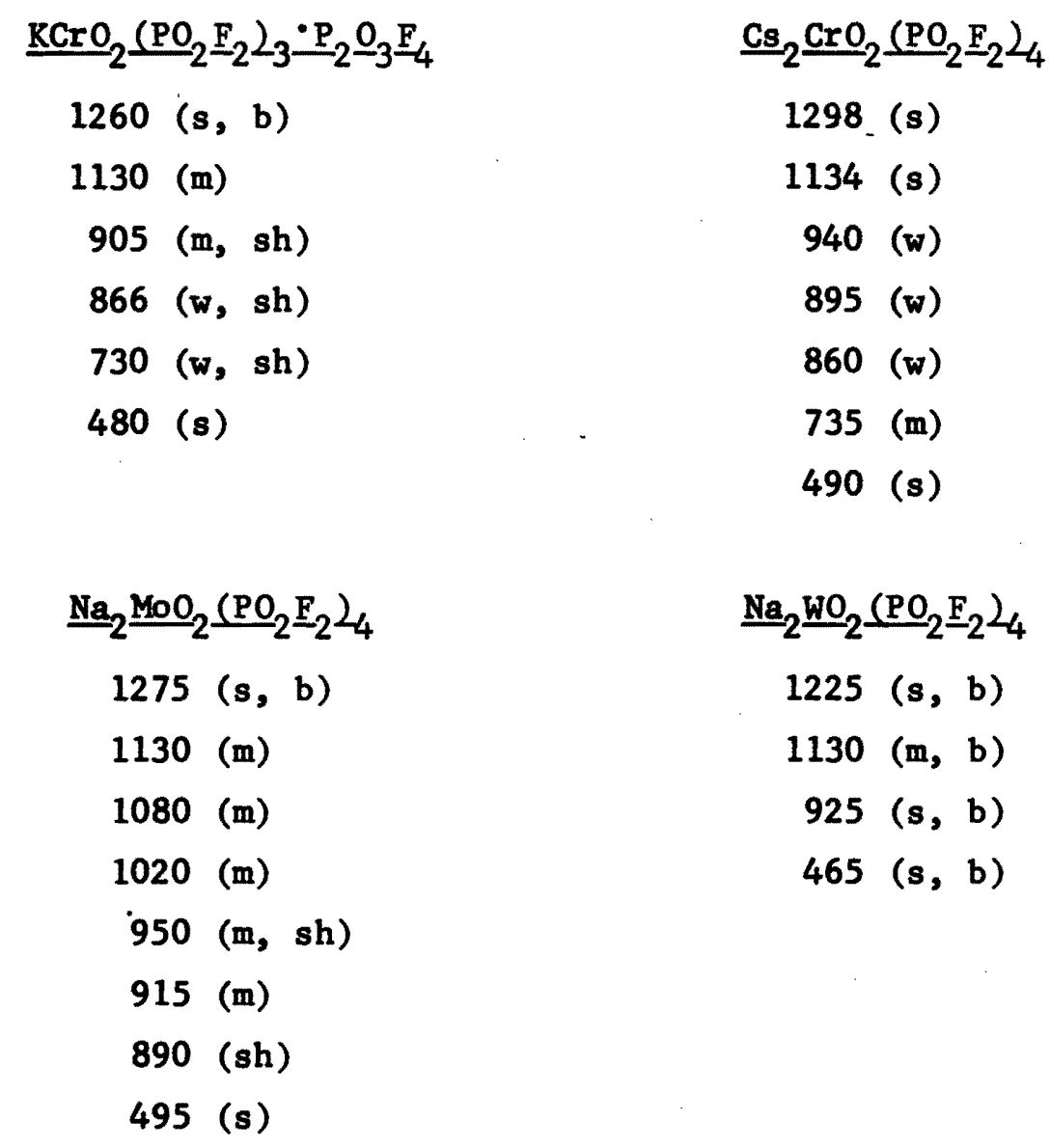




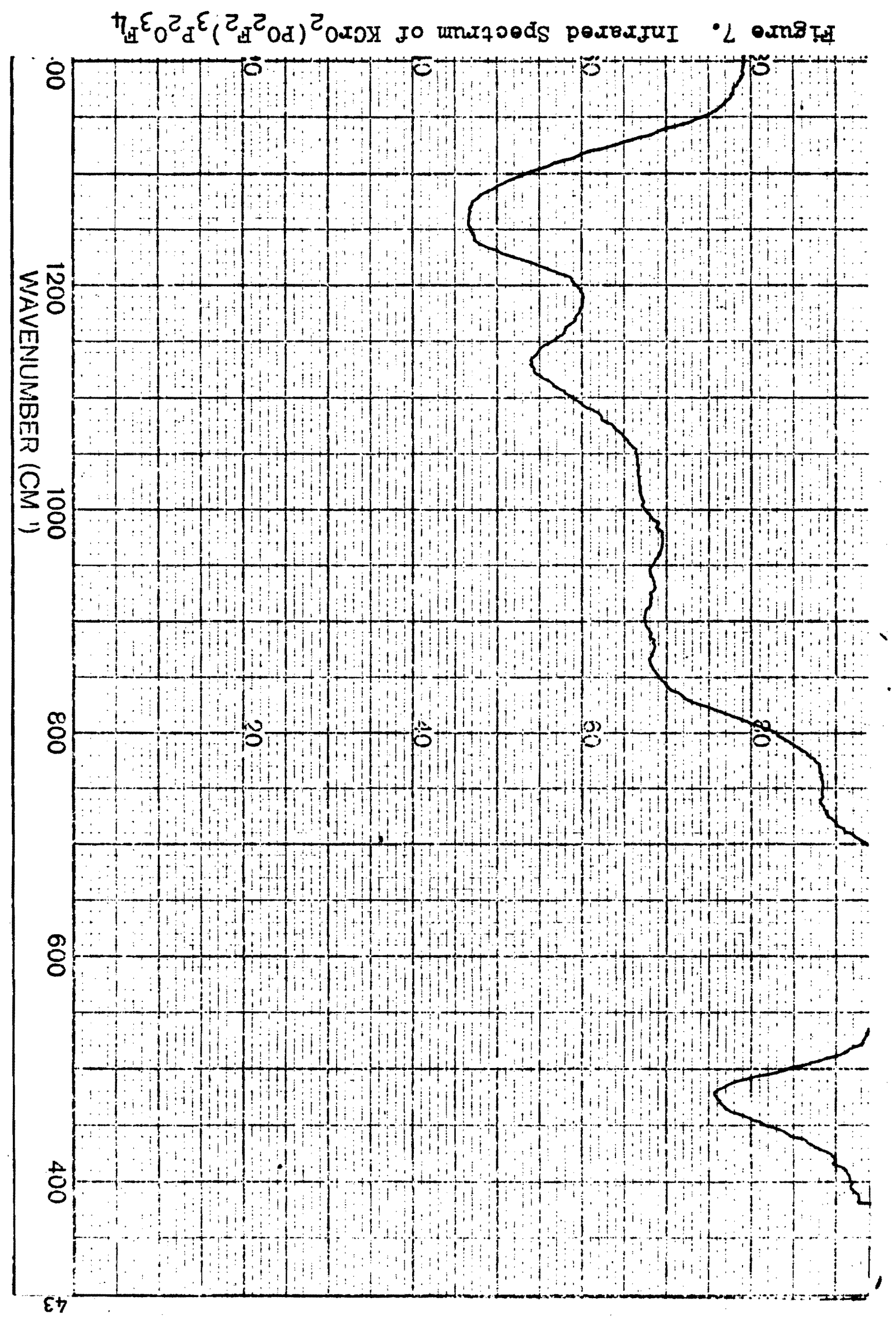




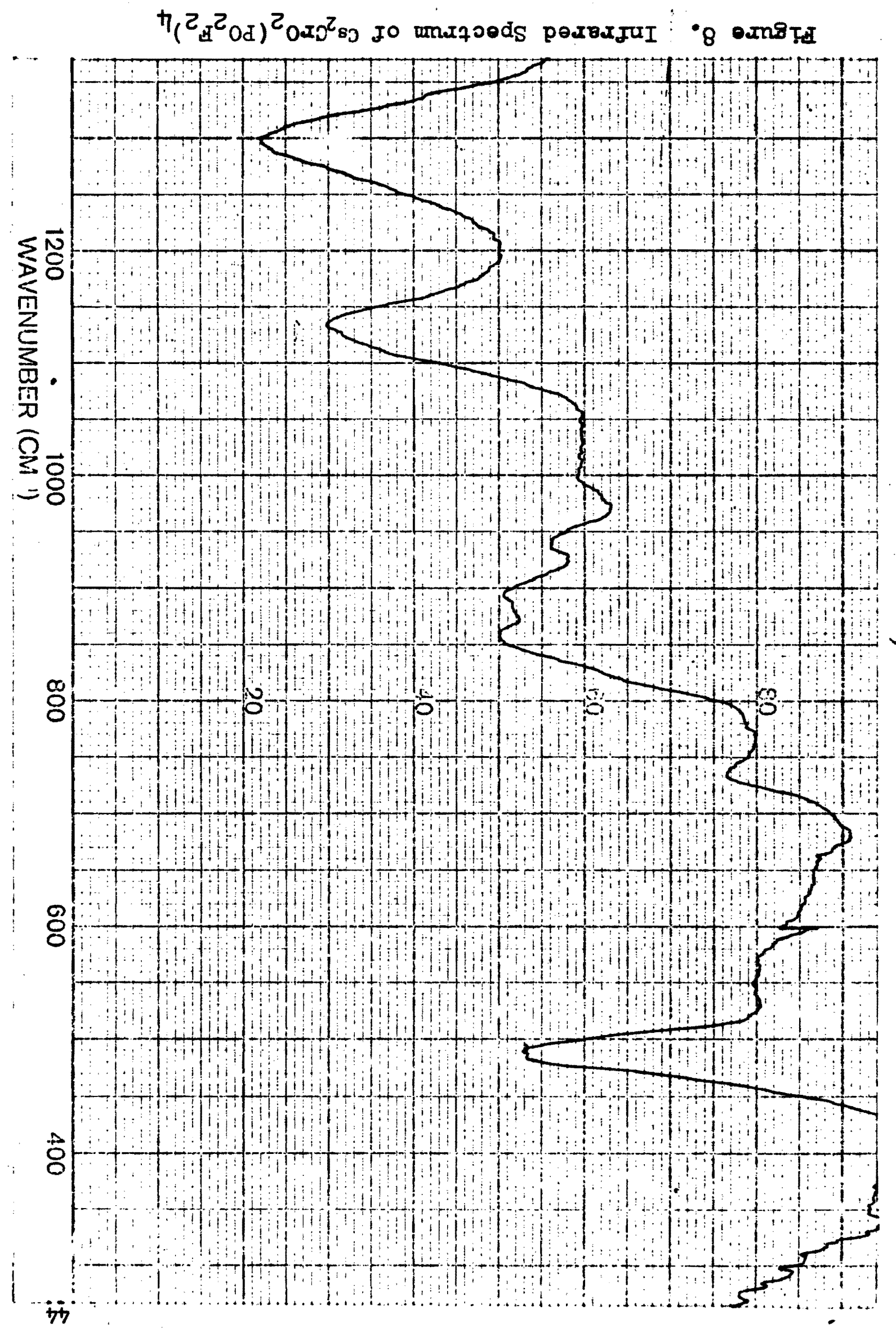




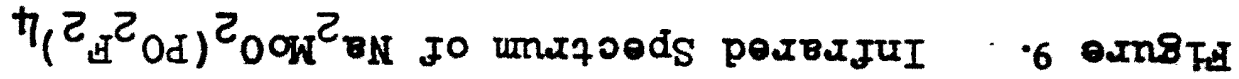

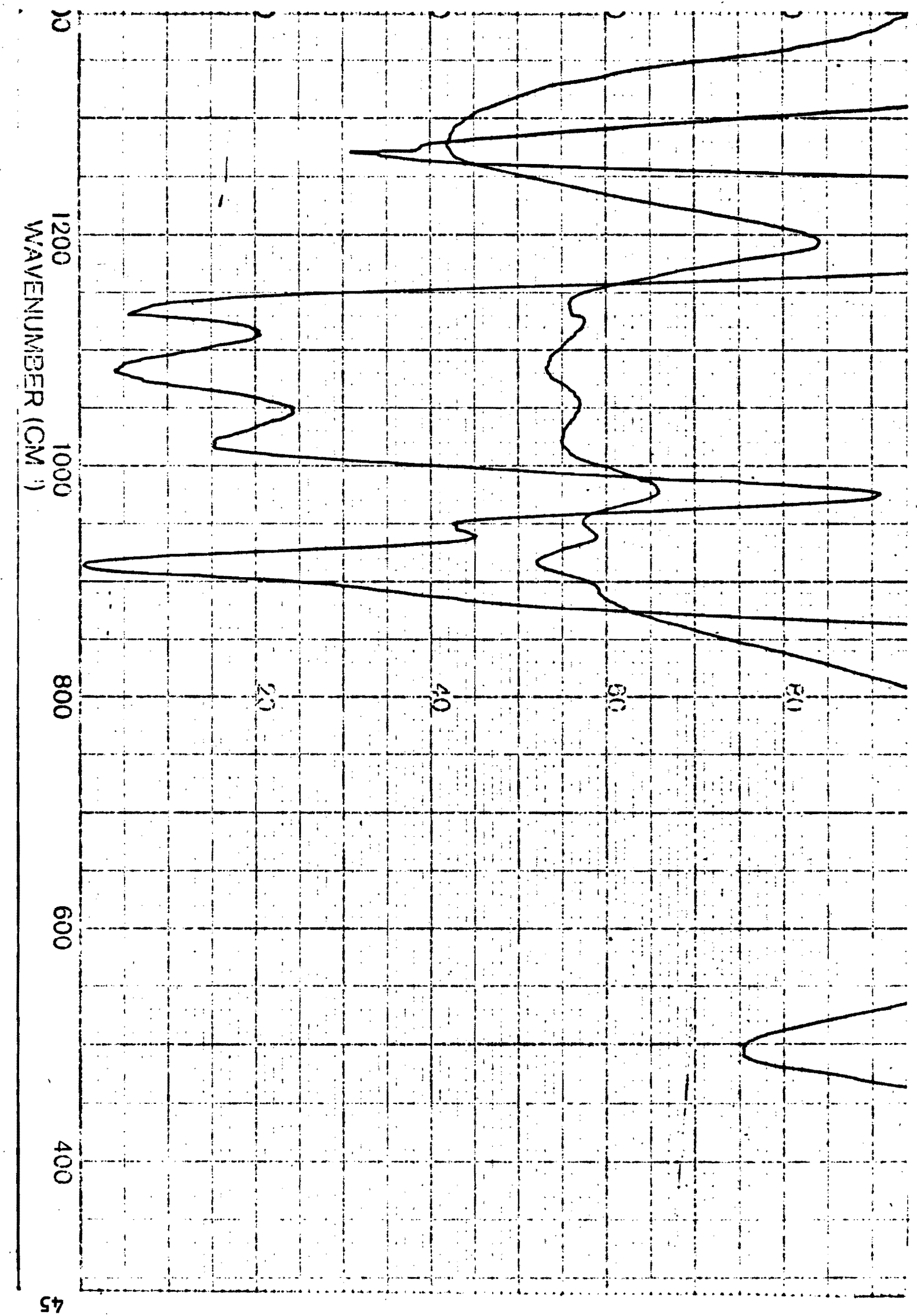




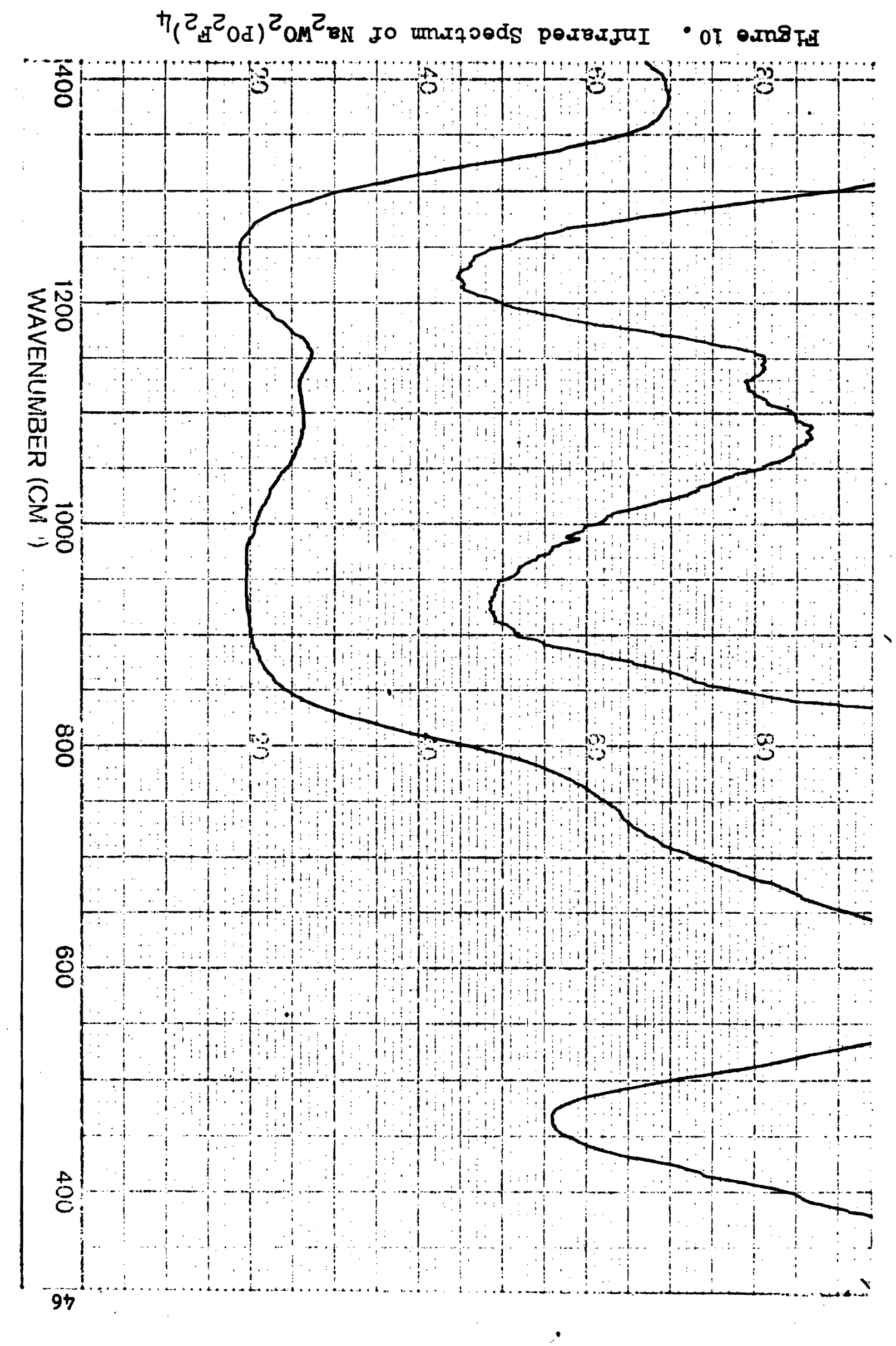


frequencies (41). This has also been observed in fluorosulfates (65):

\section{B. Reaction of $\left(\mathrm{CF}_{3} \mathrm{SO}_{2}\right)_{2}{ }_{2}{ }_{\text {with }} \mathrm{K}_{2} \mathrm{CrO}_{4}$}

1. Introduction. The reaction of potassium chromate with $\left(\mathrm{CF}_{3} \mathrm{CO}\right)_{2} \mathrm{O}$ studied by Gerlach (47):

$$
\mathrm{K}_{2} \mathrm{CrO}_{4}+2\left(\mathrm{CF}_{3} \mathrm{CO}\right)_{2} \mathrm{O}=\mathrm{K}_{2} \mathrm{CrO}_{2}\left(\mathrm{CF}_{3} \mathrm{COO}\right)_{4}
$$

suggests that $\left(\mathrm{CF}_{3} \mathrm{SO}_{2}\right)_{2} \mathrm{O}$ may react similarly. The reaction of $\left(\mathrm{CF}_{3} \mathrm{SO}_{2}\right)_{2} \mathrm{O}$ with $\mathrm{K}_{2} \mathrm{CrO}_{4}$ occurs readily at $50^{\circ}$ :

$$
\mathrm{K}_{2} \mathrm{CrO}_{4}+2\left(\mathrm{CF}_{3} \mathrm{SO}_{2}\right)_{2} \mathrm{O}=\mathrm{K}_{2} \mathrm{CrO}_{2}\left(\mathrm{CF}_{3} \mathrm{SO}_{3}\right)_{4}
$$

The product is a light brown.solid melting at $178^{\circ}$.

\section{Experimental.}

a. Preparation. To 3.10 mmoles of $\mathrm{K}_{2} \mathrm{CrO}_{4}$ contained in an $100 \mathrm{ml}$ Pyrex reaction bulb held at $-196^{\circ}, 11.2$ moles of $\left(\mathrm{CF}_{3} \mathrm{CO}_{2}\right)_{2} \mathrm{O}$ was vacuum distilled. The vessel was allowed to warm to room temperature. Initially a gold colored solid is obtained which gradually turns brown upon heating at $50^{\circ}$. The reaction was allowed to stir for one week via a Teflon covered stirring bar. The excess anhydride was removed by pumping through a trap held at $-196^{\circ}$ for one week. Final weight corresponded to $\mathrm{K}_{2} \mathrm{CrO}_{2}\left(\mathrm{CF}_{3} \mathrm{SO}_{3}\right)_{4} \cdot 0.01\left(\mathrm{CF}_{3} \mathrm{SO}_{2}\right)_{2} 0$.

b. Chemical Analysis. The chemical analysis of the compound was in very good agreement with the expected composition. Cr.6.8\% (found $6.7 \%$ ); C $6.3 \%$ (found $6.4 \%$ ); F $30.1 \%$ (found $30.4 \%$ ).

c. Infrared Spectra. The infrared spectrum shown in Figure 11 contained the following absorption and probable assignments $\left(\mathrm{cm}^{-1}\right)$ : 1310 (m), asymmetric $\mathrm{sO}_{2}-0$ stretch $(66) ; 1195(\mathrm{~s}, \mathrm{sh}), \mathrm{sO}_{2}-0$ symmetric 


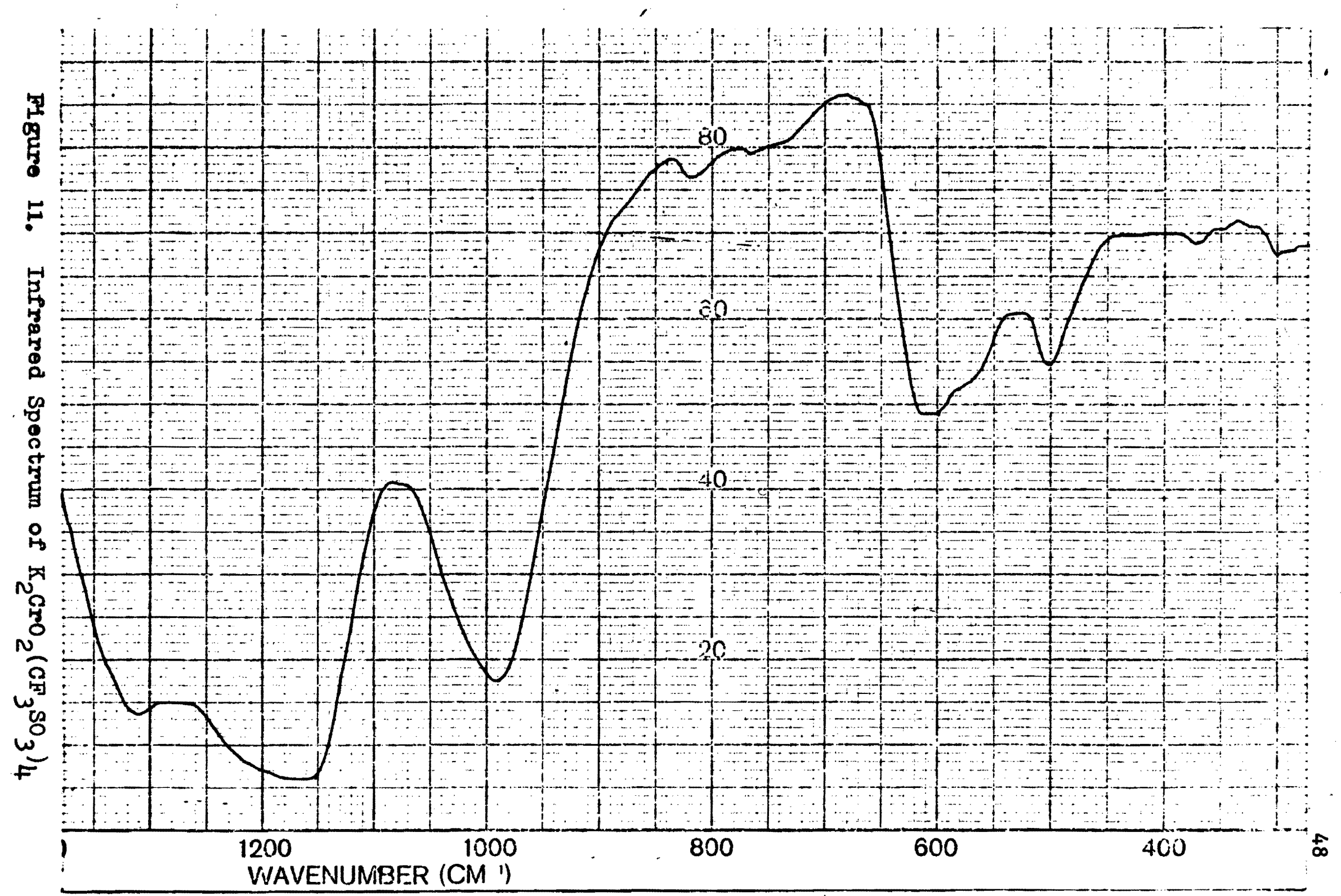


stretch; $1180-1160$ (s,b), C-F asymmetric stretch (47); 990 (s), Sr-0-Cr stretch (47); $820(w), \mathrm{CF}_{3}$ symmetric stretch (47); 620

(m), C-S stretch (66); 580-570. (s,wh); 503 (m).

d. X-Ray Powder Photograph. An x-ray spectra photograph

was also taken of the soild, the data is given in Table VI. Com-

parison with the $x$-ray spectra of $\mathrm{K}_{2} \mathrm{CrO}_{4}$ showed that no unreacted potassium chromate was present. 
TABLE VI

X-RAY POWDER SPECTRA FOR $\mathrm{K}_{2} \mathrm{CrO}_{2}\left(\mathrm{CF}_{3} \mathrm{SO}_{3}\right)_{4}$

$\begin{array}{llll}\mathrm{d}, \AA & \mathrm{I} & \mathrm{d}, \AA & \mathrm{I} \\ 15.44 & \mathrm{w} & 3.47 & \text { w } \\ 10.67 & \text { w } & 3.22 & \mathrm{~s} \\ 8.84 & \mathrm{~s} & 3.28 & \mathrm{~m} \\ 7.78 & \mathrm{~s} & 2.88 & \text { w } \\ 6.09 & \text { w } & 2.78 & \text { w } \\ 5.29 & \mathrm{~m} & 2.69 & \text { w } \\ 4.90 & \mathrm{~m} & 2.10 & \text { w } \\ 4.68 & \text { s } & 2.02 & \text { w } \\ 4.32 & \mathrm{~m} & 1.92 & \text { w } \\ 3.87 & \text { s } & 1.70 & \text { w } \\ 3.69 & \text { w } & 1.49 & \text { w }\end{array}$




\section{BIBLIOGRAPHY}

1. T.E. Thorpe and W. Kirman, J. Chem. Soc., 61; 921 (1892).

2. W. Traube, Ber., 46, 2513 (1913).

3. Ibid., 2525 (1913).

4. E. L. Muetterties and D.C. Coffman, J. Am. Chem. Soc., 80, 5914 (1958).

5. E. Hayek, A. Czaloun, and B. Krisman, Monatsh., 87, 741 (1956).

6. A. Engelbreckt, A. Aignesbeger, and E. Hayek, Monatsh., 86, 470 (1955).

7. A. A. Woolf, J. Chem. Soc., 4113 (1954).

8. M. Schmeisser and F.L. Ebenhoch, Agnew. Chem., 66, 230 (1954).

9. M. Schmeisser and W. Fink, Agnew. Chem., 69, 780 (1957).

10. J. Meyer and G. Schramm. 2. Anorg. Allgem. Chem., 206, 28 (1952).

11. W. Traube, German Patent 346,245 (1921); reference by W. Lange, Fluorine Chemistry. (J. H. Simon, ed.), Academic Press, (New York, 1950), Vol. I, P. 176 .

12. J.D. Calfee, US Patent 2,628,972 (1953); Chem. Abs., 46, 1413 (1954).

13. W. Lange, Ber., 60, 967 (1927).

14. D.R. Goddard, et a1., J. Chem. Soc., 2559 (1950).

15. E. Hayek, Monatsh., 85, 359 (1954).

16. M. Hauptschein, J. Am. Chem. Soc., 83, 2505 (1961).

17. A. Engèlbreckt, Angew. Chem. Internat. Edit., 4, 644 (1965).

18. W. Traube, et al., Ber., 52B, 1272 (1919).

19. J. Barr, R. J. Gillespie, and R.C. Thompson, Inorg. Chem., 3, 1149 (1964).

20. 0. Ruff, Ber., 47, 656 (1914).

21. E. Hayek, et a1., Mh. Chem., 87, 741 (1956). 
22. R.J. Gillespie, Acc. Chem. Res., 1 (7), 208 (1968).

23. A.A. Woolf, J. Chem. Soc. (A), 356 (1967).

24. Ibid., 99 (1967).

25. D.D. DesMarteau and M. Eisenberg, Inorg. Chem., 11 (11), 2641 (1972).

26. J.E. Roberts and G.H. Cady, J. Am. Chem. Soc., 81, 4166 (1959).

27. A.M. Qureshi, L.E. Levchuk, and F. Aubke, Can. J. Chem., 49, 2544 (1971).

28. J.E. Roberts and G.H. Cady, J. Am. Chem. Soc., 82, 353 (1960).

29. J.M. Shreeve and G.H. Cady, J. Am. Chem. Soc., 83, 4521 (1961).

30. M. Lustig and G.H. Cady, Inorg. Chem. 1, 714 (1962).

31. G.C. Kleinkopf and J.M. Shreeve, Inorg. Chem. 3, 607 (1964).

32. R. Dev and G.H. Cady, Inorg. Chem. 10, 2354 (1971).

33. Ibid., 11, 1134 (1972).

34. W.V. Rochat and G.L. Gard, Inorg. Chem., 8, 158 (1969).

35. C. Tarbutton, et al., I. Am. Chem. Soc., 63, 1782 (1941).

36. W. Lange and R. Livingston, I. Am. Chem. Soc., 72, 1280 (1950).

37. L.C. Mosier and W.E. White, Ind. Eng. Chem., 43, 246 (1951).

38. H. Jones, German Patent 813,848 (1951); reference by R. Schmutzler, Advances in Fluorine Chemistry. (M. Stacey, ed.), Butterworths, (Wash., 1965), Vol. V, p. 189.

39. C. Stolzer and A. Simon, Chem. Ber., 96, 453 (1963).

40. J. Weidlein, Z. Anorg. Chem., 358, 13 (1968).

41. R.C. Thompson and W. Reed, Inorg. Nuc1. Chem. Letters, 5, 581 (1969).

42. R.J. Gillespie, J. Barr, and R.C. Thompson, Inorg. Chem., 3, 1149 (1964).

43. U. Wannagat, ‥ Anorg. Al1g. Chem., 289, 66 (1957).

44. E.A. Robinson, Can. J. Chem., 40, 1725 (1962).

45. D.D. DesMarteau, Inorg. Chem., 10 (7), 1549 (1971).

46. D.D. DesMarteau, J. Fluorine Chem., 2, $315(1972 / 73)$. 
47. J.N. Gerlach and G.L. Gard, Inorg. Chem., 10, 1541 (1971).

48. F.A. Cotton, et al., J. Am. Chem. Soc., 83, 4157 (1961).

49. P.W. Selwood, Magnetochemistry, 2nd ed. Interscience, (New York, 1956), p. 78 .

50. F.B. Dudley and G.H. Cady, J. Am. Chem. Soc., 79, 513 (1957).

51. D.D. DesMarteau, PhD Thesis, Univ. of Wash., Seattle, Wash., 1966.

52. W.L. Jolly, The Synthesis and Chacterization of Inorganic Compounds. Prentice-Hal1, (New Jersey, 1970), p. 116.

53. H.A. Carter et al., Inorg. Chem., 9 (11), 2485 (1970).

54. J.M. Shreeve, PhD Thesis, Univ. of Wash., Seattle, Wash., 1961.

55. Reference 52, p. 381 .

56. E.H.P. Cordfunke, The Chemistry of Uranium. Elsevier, (New York, 1969), p. 213.

57. B.N. Figgis and J. Lewis, Prog. Inorg. Chem., 6, 41 (1964).

58. R.M. Dell and N. Bridger, Inorganic Chemistry, Series One (H.J. Emeleus ed.), Butterworth (London, 1972), Vo1. VII, p. 247.

59. A.A. Woolf, New Pathways in Inorganic Chemistry. (E.A.V. Ebsworth ed.). Cambridge Univ. Press (Cambridge, 1968), p. 358.

60. M. Picon and J. Flahaut, Bull. Soc. Chim. France, 772, (1958).

61. Von W. Rudorff and W. Menzer, Z. Anorg. Allgem. Chem., 292, 197 (1957).

62. J. Selbin, J. Inorg. Nucl. Chem., 32, 3249 (1970).

63. R.C. Thompson, Inorganic Sulphur Chemistry. (G. Nickless ed.), Elsevier, (New York, 1968), p. 592 .

64. P.A. Yeats, J.R. Sams, and F. Aubke, Inorg. Chem., 12 (2), 328 (1973).

65. D.W.A. Sharp, J. Chem. Soc., 3761 (1957).

66. R.T. Conley, Infrared Spectroscopy. Allyn and Bacon, (Boston, 1966), p. 181 . 